\title{
CAPITAL CONTROLS: THEORY AND EVIDENCE
}

\author{
Bilge Erten \\ Anton Korinek \\ José Antonio Ocampo \\ Working Paper 26447 \\ http://www.nber.org/papers/w26447
}
NATIONAL BUREAU OF ECONOMIC RESEARCH
1050 Massachusetts Avenue
Cambridge, MA 02138
November 2019

This manuscript was prepared for the Journal of Economic Literature. We thank our editor Steven Durlauf as well as three anonymous referees for helpful comments and Dennis Quinn for generously sharing data on capital control indices. Additionally, we are grateful for insightful discussions with Chang Ma, Olivier Jeanne, Alessandro Rebucci, and Joseph Stiglitz as well as research assistance by Daniel Harper, Mrithyunjayan Nilayamgode, and Hasan Toprak. Korinek acknowledges financial support from the Institute for New Economic Thinking (INET). The views expressed herein are those of the authors and do not necessarily reflect the views of the National Bureau of Economic Research.

NBER working papers are circulated for discussion and comment purposes. They have not been peer-reviewed or been subject to the review by the NBER Board of Directors that accompanies official NBER publications.

(C) 2019 by Bilge Erten, Anton Korinek, and José Antonio Ocampo. All rights reserved. Short sections of text, not to exceed two paragraphs, may be quoted without explicit permission provided that full credit, including $\odot$ notice, is given to the source. 
Capital Controls: Theory and Evidence

Bilge Erten, Anton Korinek, and José Antonio Ocampo

NBER Working Paper No. 26447

November 2019

JEL No. D62,E44,F32,F38,F42,H23

\begin{abstract}
$\underline{\text { ABSTRACT }}$
This paper synthesizes recent advances in the theoretical and empirical literature on capital controls. We start by observing that international capital flows have both benefits and costs, but some of these are not internalized by individual actors and thus constitute externalities. The theoretical literature has identified pecuniary externalities and aggregate demand externalities that respectively contribute to financial instability and recessions. These externalities provide a natural rationale for counter-cyclical capital controls that lean against boom and busts cycles in international capital flows. The empirical literature has developed several measures of capital controls to capture different aspects of capital account openness. We evaluate the strengths and weaknesses of different measures and provide an overview of the empirical findings on the effectiveness of capital controls in addressing the externalities identified by the theory literature, i.e. in reducing financial fragility and enhancing macroeconomic stability. We also discuss strategies to deal with the endogeneity of capital controls in such statistical exercises. We conclude by providing an overview of the historical and current debates on the role of capital controls in macroeconomic management and their relationship to the academic literature.
\end{abstract}

Bilge Erten

Northeastern University

Economics Department

Boston, MA 02115

erten.bilge@gmail.com

Anton Korinek

Department of Economics

University of Virginia

Monroe Hall 246

248 McCormick Rd

Charlottesville, VA 22904

and NBER

anton@korinek.com
José Antonio Ocampo

Columbia University

New York, NY 10027

ocampo.joseantonio@yahoo.com

Teaching materials including slides are available at http://www.korinek.com/capitalcontrols 
Integration into global capital markets exposes economies to boom and bust cycles in international capital flows. In good times, capital inflows often generate overheating; in bad times, the reversal of capital flows often triggers recessions and financial crises. It has been documented that increased capital market liberalization is associated with increased financial and macroeconomic instability (Reinhart and Rogoff, 2009; Gallagher, Griffith-Jones, and Ocampo, 2012). Given the high welfare costs of financial crises, policymakers in a number of emerging markets have responded by actively managing international capital flows, for example by imposing counter-cyclical capital controls that are tightened during booms and relaxed during busts (Ostry et al. 2010; Ocampo, 2017 , ch. 4). In earlier decades, the economic literature had little guidance to offer to policymakers on why it may be desirable to intervene in the free market equilibrium, how to optimally regulate capital flows, and what the welfare implications of international spillovers from such policies may be.

We synthesize the recent theoretical and empirical literature on capital controls and discuss to what extent the resulting framework can provide useful guidance to academics and policymakers on how to optimally regulate international capital flows. Recent theoretical advances show that private capital flows may lead to macroeconomic externalities, i.e. externalities that increase financial instability and interfere with aggregate demand management at the macroeconomic level. A novel strand of literature demonstrates that these externalities lead private agents to over-borrow and take on excessive risks. The theoretical literature has proposed that these externalities can be corrected by counter-cyclical capital account interventions. In this article, we integrate these theoretical predictions with recent empirical literature that has investigated the effectiveness of capital account regulations in reducing financial fragility and enhancing macroeconomic stability. Finally, we evaluate the policy implications for how emerging market economies can incorporate capital account regulations into their policy tool kits, and we discuss whether there is a need for global economic coordination to reduce their spillover effects across countries. ${ }^{1}$

An initial comment on terminology is in order. The term "capital controls" refers to interventions in the capital account, which is the part of the balance of payments that records financial transactions between domestic and foreign actors. "Capital controls" is also the term used by the IMF Articles of Agreement for such interventions. Some of us prefer, however, the term "capital account regulations," and indeed they are now widely considered part of the family of macroprudential regulations. Still other authors refer to capital controls as "capital account management," and the IMF has recently called them "capital flow management (CFM) measures" in its Institutional View on this issue (IMF, 2012). We will use the terms synonymously throughout this paper.

The reminder of the paper is organized as follows. Section 1 examines recent theoretical advances in how capital controls can be used to correct for macroeconomic externalities. Section 2 presents an overview of the varieties

\footnotetext{
${ }^{1}$ For complementary surveys of the literature, see also Jeanne, Subramanian, and Williamson (2012) and Rebucci and Ma (2019).
} 
of capital control measures and reviews the empirical evidence on their effectiveness. Section 3 reviews historical and current policy debates on the role of capital controls in macroeconomic management and their relationship to the academic literature, and Section 4 provides some brief conclusions.

\section{Theory: Externalities of Capital Flows}

The conventional wisdom of the 1990s was that all countries should aim to liberalize their capital accounts, based on a perhaps naïve application of the first welfare theorem to international capital flows. In stylized textbook models, exemplified by Obstfeld and Rogoff (1996), openness to international borrowing and lending generates the traditional gains from trade on both sides of the transaction. In the recipient country, capital inflows can be invested in productive investments, or alternatively, allow domestic agents to smooth their consumption. In the source country, lenders earn higher returns to their capital and achieve greater diversification of their assets and liabilities. In addition to these neoclassical benefits, foreign investment, especially in the form of FDI, may lead to technology transfer, and if this occurs in the financial system, enhance financial development. The main implication of this view is that the presence of capital controls that restrict such mutually-beneficial transactions would reduce economic efficiency and welfare. Following this conventional wisdom, many economists at the time argued that all countries should aim to liberalize their capital accounts (see e.g. Dornbusch, 1998; Summers, 2000; and Fischer, 2003).

The East Asian crisis of 1997-98 thoroughly shook the mainstream view prevailing at the time by showing that large private capital flows can render even relatively well-governed economies vulnerable to catastrophic financial crises. This triggered a growing literature that emphasizes how free capital flows may magnify market imperfections that lead to instability and crisis (Bhagwati, 1998; Rodrik, 1998; and Stiglitz, 2002). In the early 2000s several countries that had liberalized their capital account began to reintroduce capital controls (see Figure 5 below and Klein, 2012, Table A1). This process gained momentum after the onset of the 2008-09 Global Financial Crises, ${ }^{2}$ when a number of emerging market economies, including Brazil, Korea, and Peru imposed new restrictions on capital inflows or tightened existing capital account regulations to reduce the risks created by currency appreciation and asset price inflation.

Over the past two decades, a growing number of theoretical studies have provided micro-foundations for why capital controls may enhance welfare. The common theme of this strand of literature is that capital flows may generate externalities that private agents do not internalize. The main categories of such externalities emphasized by the literature are pecuniary externalities, associated with financial instability, and aggregate demand externalities, associated with unemployment. Such externalities induce private agents to borrow too much,

\footnotetext{
${ }^{2}$ From the perspective of emerging developing countries, the 2008-09 crisis should be more adequately termed the North-Atlantic Financial Crisis, as it centered in the United States and Western Europe.
} 
to buy too little insurance or take on excessive risk, and to borrow excessively short-term.

A distinct advantage of an externality view of capital controls is that it applies the lessons of modern welfare economics to the domain of international capital flows (see e.g. Korinek, 2011b). Earlier debates on the desirability of capital controls were concerned with broad questions that are difficult to answer in general such as "are international capital flows desirable or not?" By contrast, the literature on externalities emphasizes that there are clearly both benefits and costs to international capital flows, but that some of the benefits or costs may be external to the individual decision maker. If the externalities of capital flows are correctly identified and well-regulated, it can be left to the market to determine the cost/benefit analysis and decide how to allocate capital, combining the benefits of thoughtful regulation with the power of markets. In a sense, the literature on the externalities of capital flows thus has a more modest goal: instead of providing a comprehensive analysis and evaluation of the overall benefits and costs of international capital flows, it identifies and evaluates specific external benefits or costs, and leaves the comprehensive evaluation of the private benefits and costs of capital flows to the market.

In the following subsections, we first lay out a baseline model in which markets are perfect so there is no case for intervention. We next introduce a generic externality to illustrate how to design capital controls that alleviate externalities in a Pigouvian fashion. Then we will describe simple models of pecuniary externalities and aggregate demand externalities that motivate capital controls to mitigate financial instability and aggregate demand problems.

\subsection{Baseline setup}

Assume a small open economy with two time periods $t=0,1$, a unit mass $i \in[0,1]$ of identical domestic consumers and large international lenders. An individual domestic consumer $i$ has preferences

$$
U^{i}=u\left(c_{0}^{i}\right)+\beta u\left(c_{1}^{i}\right)
$$

and receives endowments of traded goods $y_{T, 0}$ and $y_{T, 1}$. She smooths consumption by purchasing $b^{i}$ units of discount bonds from international lenders. International lenders are large in comparison to the small open economy so they demand or supply bonds perfectly elastically at a gross interest rate $R=1+r$ that we assume satisfies $\beta R=1$. The domestic consumer's budget constraints are

$$
\begin{aligned}
& c_{0}^{i}=y_{T, 0}-b^{i} / R \\
& c_{1}^{i}=y_{T, 1}+b^{i}
\end{aligned}
$$

$b^{i}<0$ reflects period 0 borrowing, i.e. capital inflows from international lenders in period 0 and outflows to repay them in period 1 ; the reverse holds for $b^{i}>0$. Since there is a single representative consumer, the saving/borrowing decision $b^{i}$ also maps directly into the current account of the economy. Saving $b^{i} / R>0$ 
generates a current account and trade surplus of $b^{i} / R>0$ in period 0 and a current account and trade deficit of $b^{i}$ in period 1 , and vice versa if $b^{i}<0$.

We denote the period 0 optimization problem of consumer $i$ as

$$
\max _{b^{i}} U^{i}=\max _{b^{i}} u\left(y_{T, 0}-b^{i} / R\right)+\beta V\left(b^{i}\right)
$$

where period 1 continuation utility of consumer $i$ for given borrowing $b^{i}$ is given by the value function

$$
V\left(b^{i}\right)=u\left(y_{T, 1}+b^{i}\right)
$$

All our models of externalities below will build on the basic structure of optimization problem (3), but different economic environments will map into different continuation utility functions $V(\cdot)$.

The consumer's optimality condition gives rise to the Euler equation

$$
\begin{aligned}
u^{\prime}\left(c_{0}^{i}\right) & =\beta R V_{b}\left(b^{i}\right) \\
& =u^{\prime}\left(c_{1}^{i}\right)
\end{aligned}
$$

which implies perfect consumption smoothing. Together with the budget constraints, this yields $c_{0}^{i}=c_{1}^{i}=\left(y_{T, 1}+R y_{T, 0}\right) /(1+R)$ and $b^{i}=c_{1}^{i}-y_{T, 1}$.

Welfare Analysis From the perspective of a domestic policymaker who determines the external bond allocation of the economy, domestic welfare is given by the optimization problem

$$
W=\max _{B} u\left(y_{T, 0}-B / R\right)+\beta V(B)
$$

The only difference from the individual consumer problem is that the policymaker chooses aggregate bond holdings $B$ of the economy instead of the individual bond holdings $b^{i}$ of consumer $i$. However, the problem yields the same Euler equation (4), the same borrowing choice and the same consumption allocation for domestic consumers. This is unsurprising since there are no market imperfections in our baseline setup. ${ }^{3}$ The decentralized allocation is thus socially efficient and policy intervention cannot achieve a Pareto improvement compared to the decentralized allocation. In the following subsections, we will break this result and introduce externalities that provide a motive for capital controls rooted in economic theory.

\subsection{Introducing Externalities}

We introduce a generic externality into our baseline setup to illustrate how to employ capital controls to internalize externalities. Assume that an aggregate level of bond holdings $B$ imposes an externality $\varepsilon(B)$ with $\varepsilon^{\prime}(B)>0$ on consumers in period 1 , which is not internalized by the individual consumer. (Since

\footnotetext{
${ }^{3}$ More specifically, markets are complete, all agents are price-takers and preferences are locally non-satiated, satisfying the conditions of the first welfare theorem.
} 
debt corresponds to negative bond holdings, this implies that the marginal social benefit of additional borrowing is negative, $-\varepsilon^{\prime}(B)<0$.) We will provide detailed micro-foundations for externalities of debt in the context of pecuniary externalities and of aggregate demand effects below. ${ }^{4}$ For now, we capture the externality by the generic term $\varepsilon(B)$ to describe how to analyze the externalities of borrowing in the simplest possible setting. The externality modifies the period 1 budget constraint of consumers to

$$
c_{1}^{i}=y_{T, 1}+b^{i}+\varepsilon(B)
$$

The continuation utility of consumer $i$ in period 1 is then given by the value function

$$
V\left(b^{i} ; B\right)=u\left(y_{T, 1}+b^{i}+\varepsilon(B)\right)
$$

Notice that consumer $i$ 's value function now depends both on her individual bond holdings $b^{i}$, which determine her repayment, and on aggregate bond holdings in the economy, which determine the externality. Even though each consumer experiences the externality $\varepsilon(B)$, she rationally recognizes that aggregate bond holdings are the result of their collective behavior $B=\int_{0}^{1} b^{i} d i$, and the contribution of each individual consumer $j$ is negligible, $d B / d b^{j}=0$. As a result, she simply takes aggregate bond holdings as given in her optimization problem. An individual consumer solves optimization problem (3) with this new value function and arrives at the Euler equation

$$
\begin{aligned}
u^{\prime}\left(c_{0}^{i}\right) & =\beta R V_{b}\left(b^{i} ; B\right) \\
& =u^{\prime}\left(c_{1}^{i}\right)
\end{aligned}
$$

Both lines are analogous to the Euler equation (4) in our baseline model. As a result, domestic agents smooth consumption as in our baseline model. Aggregate consumption and borrowing are given by the system of equations $c_{0}=c_{1}=\left(y_{T, 1}+\varepsilon(B)+R y_{T, 0}\right) /(1+R)$ and $B=c_{1}-y_{T, 1}-\varepsilon(B)$.

Welfare Analysis A policymaker, by contrast, internalizes the externalities of international capital flows and solves

$$
W=\max _{B} u\left(y_{T, 0}-B / R\right)+\beta V(B ; B)
$$

which yields the optimality condition

$$
\begin{aligned}
u^{\prime}\left(c_{0}\right) & =\beta R\left[V_{b}(B ; B)+V_{B}(B ; B)\right] \\
& =u^{\prime}\left(c_{1}\right)\left[1+\varepsilon^{\prime}(B)\right]
\end{aligned}
$$

\footnotetext{
${ }^{4}$ Additional reasons why foreign borrowing may impose externalities on consumers include negative effects of capital inflows on competitiveness, and the risk that high levels of foreign borrowing may give rise to bailouts that are ultimately borne by consumers.
} 
The partial derivative with respect to the first argument $V_{b}\left(b^{i} ; B\right)=u^{\prime}\left(c_{1}\right)$ reflects the direct benefit of an additional unit of bond holdings, and the partial derivative with respect to the second argument $V_{B}\left(b^{i} ; B\right)=u^{\prime}\left(c_{1}\right) \varepsilon^{\prime}(B)>$ 0 reflects the marginal externality cost of aggregate bond holdings. In the planner's Euler equation 8 , note that $b^{i}=B$ since the planner internalizes that she simultaneously chooses both individual and aggregate bond holdings. The planner's Euler equation reflects that there is an extra benefit to holding more bonds (and borrowing less); her optimal allocation thus satisfies $c_{0}<c_{1}$. Comparing the allocations chosen by the planner and by individual consumers, it is clear that the decentralized allocation exhibits excessive borrowing and consumption in period 0 .

Figure 1 depicts both the laissez-faire equilibrium of the economy and the planner's allocation in a demand/supply diagram of foreign bond holdings $b^{i}=$ $B$. For a small open economy, supply of bonds is perfectly elastic at the exogenous discount price $1 / R$, as indicated by the line $S$. The demand of an individual consumer $i$ is depicted by the downward-sloping curve $D^{i}$ that traces out the consumer's marginal rate of substitution $\beta u^{\prime}\left(c_{1}^{i}\right) / u^{\prime}\left(c_{0}^{i}\right)$ as a function of the bond position $b^{i}$. The equilibrium level of bond holdings, indicated by $b^{i *}$, occurs where supply equals demand or, analytically, at the point where

$$
\underbrace{\frac{1}{R}}_{\text {supply }}=\underbrace{\frac{\beta u^{\prime}\left(c_{1}^{i}\right)}{u^{\prime}\left(c_{0}^{i}\right)}}_{\text {demand }}
$$

The planner's effective demand curve accounts for the externality and can be represented by tracing out $\beta u^{\prime}\left(c_{1}^{i}\right)\left[1+\varepsilon^{\prime}(B)\right] / u^{\prime}\left(c_{0}^{i}\right)$ as a function of the aggregate bond position $B$. The planner's optimum, indicated by $B^{*}$, occurs at the point where

$$
\frac{1}{R}=\frac{\beta u^{\prime}\left(c_{1}^{i}\right)\left[1+\varepsilon^{\prime}(B)\right]}{u^{\prime}\left(c_{0}^{i}\right)}
$$

The planner can implement the optimal allocation in the economy using capital controls that take the form of either quantity or price regulations.

Capital Controls: Quantity Regulation Denoting by $B^{*}$ the solution to the policymaker's optimization problem (7), the optimum allocation is restored by imposing the quantity limit

$$
b^{i} \geq B^{*}
$$

on individual consumers, as indicated in Figure 1. (Recall that $b^{i}$ and $B$ denote bond holdings, which are negative in the case of borrowing; the constraint can thus be read as instructing consumers not to borrow more than $-B^{*}$ units of discount bonds.) If the capital account is closed to private transactions, a similar effect is obtained if a government entity, for example the central bank, accumulates the bond position $B^{*}$, for example in the form of reserves. 


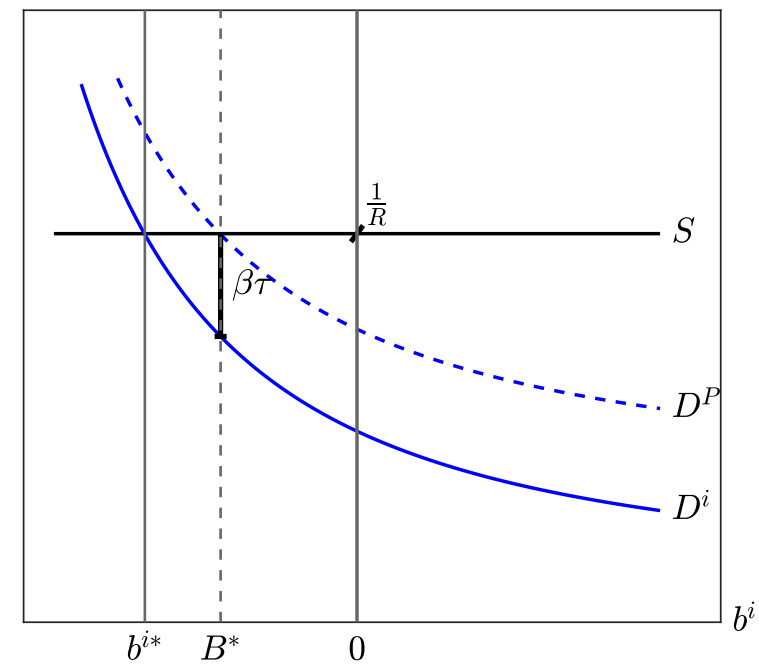

Figure 1: Demand and supply for foreign bonds

Capital Controls: Price Regulation Equivalently, the policymaker may impose a tax wedge $\tau$ on the borrowing/saving decision such that the consumer obtains only a fraction $(1-\tau)$ of the funds borrowed or pays only a fraction $(1-\tau)$ of the funds saved. We assume that the revenue from the tax is rebated to consumers (or if $\tau B>0$, the revenue required for the implied subsidy is raised from consumers) as a lump-sum transfer $T_{0}=\tau B / R$. This changes the period 0 budget constraint to

$$
c_{0}^{i}=y_{T, 0}-(1-\tau) b^{i} / R-T_{0}
$$

As can be seen from this budget constraint, the specific interpretation of $\tau$ depends on the signs of $b^{i}$ and $\tau$ and is illustrated in Table 1: if the country is a net borrower, $b^{i}<0$, then $\tau>0$ represents a tax on foreign borrowing, or a tax on capital inflows and, conversely, $\tau<0$ represents a subsidy to capital inflows; if the consumer is a net saver, $b^{i}>0$, then $\tau>0$ represents a subsidy to capital outflows whereas $\tau<0$ is a tax on outflows.

\begin{tabular}{l|c|c} 
& $\tau>0$ & $\tau<0$ \\
\hline$b^{i}>0$ (saving) & outflow subsidy & outflow tax \\
\hline$b^{i}<0$ (borrowing) & inflow tax & inflow subsidy
\end{tabular}

Table 1: Interpretation of capital control $\tau$

Solving the analogous optimization problem to (3) with the new budget constraint (12), the consumer arrives at the Euler equation

$$
(1-\tau) u^{\prime}\left(c_{0}\right)=\beta R V_{b}\left(b^{i} ; B\right)
$$


Combining the Euler equations of the policymaker (8) and of the consumer (13), we see that the two allocations coincide if we set the tax rate on the consumer to

$$
\tau=\frac{\beta R V_{B}(\cdot)}{u^{\prime}\left(c_{0}\right)}
$$

This tax rate makes the consumer internalize the externality of an additional unit of bond holdings $V_{B}(\cdot)$ that is not internalized by the individual consumers. In our specific example here, the optimal tax rate is

$$
\tau=\frac{u^{\prime}\left(c_{1}\right)}{u^{\prime}\left(c_{0}\right)} \cdot \varepsilon^{\prime}(B)>0
$$

Intuitively, this tax rate signals the social benefit of an additional unit of bond holdings (or equivalently, the social cost of an additional unit of borrowing) to the individual consumer. In Figure 1 , the tax rate $\tau$ (normalized by $\beta$ ) is given by the vertical difference between the planner's effective demand curve and the demand curve of individual consumers, as can be seen from comparing expressions (9) and (10).

Multiple State of Nature Our model of externalities is set in perfect foresight so far, but it is easy to generalize it to multiple states of nature, with either complete or incomplete financial markets. Consider an economy in which there are multiple states of nature $\omega \in \Omega$ in period 1 , together with a probability distribution $P(\omega)$ that defines an expectations operator $\mathbb{E}[\cdot]$. Any variables that depend on the state of nature are indexed by $\omega$. For example, consider an economy with two states $\Omega=\{L, H\}$ in which there are externalities from borrowing in the low state only so $\varepsilon_{B}^{L^{\prime}}(\cdot)>0=\varepsilon_{B}^{H \prime}(\cdot)$. We can then construct value functions $V^{\omega}\left(b^{i} ; B\right)$ for $\omega \in \Omega$ along the same lines as (5).

If consumers face complete financial markets, trading w.l.o.g. with riskneutral international lenders, then they choose their security holdings $b^{i, \omega}$ for each state separately by solving the optimization problem

$$
U^{i}=\max _{\left\{b^{i, \omega}\right\}_{\omega \in \Omega}} u\left(y_{T, 0}-\mathbb{E}\left[b^{i, \omega}\right] / R\right)+\beta \mathbb{E}\left[V^{\omega}\left(b^{i, \omega} ; B^{\omega}\right)\right]
$$

A policymaker would solve the analogous optimization problem for $b^{i, \omega}=B^{\omega}$ and would arrive at state-contingent quantity limits $B^{\omega *}$ or taxes on capital flows $\tau^{\omega}$ analogous to equations (11) and (14).

Alternatively, if consumers can only trade uncontingent bonds $\bar{b}^{i}$ with international lenders, their optimization problem is

$$
U^{i}=\max _{\bar{b}^{i}} u\left(y_{T, 0}-\bar{b}^{i} / R\right)+\beta \mathbb{E}\left[V^{\omega}\left(\bar{b}^{i} ; \bar{B}\right)\right]
$$

This similarly gives rise to an optimal quantity limit $\bar{B}^{*}$ or tax rate $\bar{\tau}$ on uncontingent bond holdings.

A common view is that capital flows and repayments in "low" states of nature, during recessions or crises, create negative externalities of the type that is 
captured in this model or in the ensuing subsections. By contrast, capital flows and repayments in "good" states of nature are viewed as considerably more benign. This creates a compelling case for differentiating capital controls based on the risk characteristics of the financial flows that they apply to (see Korinek, 2010, 2018).

\subsection{Balance Sheet Effects, Pecuniary Externalities, and Overborrowing}

Much of the attention of the recent theoretical literature motivating capital controls has focused on pecuniary externalities that arise from balance sheet effects. At the center of most recent financial crises were private sector borrowers who had taken on excessive leverage - in contrast with an earlier literature that focused on crises that resulted from flawed government policies such as inconsistent exchange rate regimes (see e.g. Krugman, 1979). When a large number of borrowers in an economy experience financial difficulty at the same time and engage in deleveraging, their collective actions lead to asset price declines and exchange rate depreciations, which frequently reduce the value of the assets on borrowers' balance sheets and/or increase the value of their liabilities. ${ }^{5}$ As a result, the creditworthiness of borrowers declines further, leading to a feedback loop of further deleveraging, asset price and exchange rate depreciations, and balance sheet effects. In the context of international capital flows, this mechanism of financial amplification was first described informally in Calvo (1998) as "sudden stops," and more formally by Krugman (1999a). ${ }^{6}$

Model of Pecuniary Externalities To capture such financial amplification effects as well as the resulting externalities, we consider a variant of our baseline model with three time periods, loosely based on Korinek (2011b). Consumers value only traded goods in the first and last period but a composite $c_{1}^{i}$ of traded and non-traded goods in the intermediate period 1 ,

$$
\begin{aligned}
U^{i}= & u\left(c_{T, 0}^{i}\right)+\beta u\left(c_{1}^{i}\right)+\beta^{2} u\left(c_{T, 2}^{i}\right) \\
& \text { where } \quad c_{1}^{i}=c\left(c_{T, 1}^{i}, c_{N, 1}^{i}\right)=\sqrt{c_{T, 1}^{i} c_{N, 1}^{i}}
\end{aligned}
$$

Consumers receive exogenous endowments of all goods $y_{T, t}$ and $y_{N, 1}$ where we normalize $y_{N, 1}=1$. They trade discount bonds $b_{1}^{i}$ and $b_{2}^{i}$ that pay off one unit of traded good in periods 1 and 2 respectively, giving rise to a period 0 budget

\footnotetext{
${ }^{5}$ These valuation effects of assets and liabilities on borrowers' balance sheets, which in turn affect the financial health of borrowers and have real effects because of financial market imperfections, are what the literature calls "balance sheet effects."

${ }^{6}$ Krugman was also the first to suggest that there was an externality at work when there is a currency mis-match between assets and liabilities, observing that "Loosely speaking, there appears to be a sort of external diseconomy to borrowing in foreign currencies" (p. 21 in Krugman, 1999a).
} 
constraint equivalent to (1) and the period 1 and 2 budget constraints

$$
\begin{aligned}
c_{T, 1}^{i}+p_{N} c_{N, 1}^{i}+b_{2}^{i} / R & =y_{T, 1}+p_{N} y_{N, 1}+b_{1}^{i} \\
c_{T, 2}^{i} & =y_{T, 2}+b_{2}^{i}
\end{aligned}
$$

where $p_{N}$ is the relative price of non-traded goods in terms of traded goods (or real exchange rate) in period 1 and debt is denoted in traded goods. ${ }^{7}$ To capture balance sheet effects in a simple manner, we introduce a financial constraint of the general form,

$$
b_{2}^{i} / R \geq-\phi\left(p_{N}\right)
$$

which satisfies $0<\phi^{\prime}\left(p_{N}\right)<1$, i.e. the maximum amount of borrowing is capped by a function $\phi(\cdot)$ that is increasing in $p_{N}$. This constraint reflects that a lower value of non-traded goods reduces the value of collateral such as land held by borrowers and therefore lowers the amount of debt $-b_{2}^{i} / R$ that borrowers can take on. A particularly common version of this constraint in the literature (see e.g. Mendoza, 2005; Korinek, 2007, 2018; Bianchi, 2011; Benigno et al., 2013) is

$$
b_{2}^{i} / R \geq-\kappa\left[y_{T, 1}+p_{N} y_{N, 1}\right]
$$

In this version of the constraint, the derivative $\phi^{\prime}\left(p_{N}\right) \equiv \kappa y_{N, 1}=\kappa$ is a constant and explicit solutions can be obtained for our model. The precise form of the constraint is irrelevant; what matters for our results here is that borrowing capacity depends positively on the level of the real exchange rate, as suggested by empirical evidence.

We solve the model via backward induction and focus on equilibrium in periods 1 and 2 first. Consumers accordingly solve the period 1 optimization problem

$$
\max _{c_{T, 1}^{i}, c_{N, 1}^{i}, b_{2}^{i}} u\left(\sqrt{c_{T, 1}^{i} c_{N, 1}^{i}}\right)+\beta u\left(y_{T, 2}+b_{2}^{i}\right) \quad \text { s.t. (17), (18) }
$$

with optimality conditions

$$
\begin{aligned}
u_{T, 1}^{i} & =\beta R u^{\prime}\left(c_{T, 2}^{i}\right)+\lambda^{i} \\
p_{N} & =c_{T, 1}^{i} / c_{N, 1}^{i}
\end{aligned}
$$

where $u_{T, 1}^{i}=\partial u(\cdot) / \partial c_{T, 1}^{i}$ and $\lambda^{i}$ is the shadow price on the financial constraint (18).

In a symmetric equilibrium, the second optimality condition (20) together with market clearing for non-traded goods $c_{N, 1}^{i}=y_{N, 1}=1$ implies that $p_{N}=c_{T, 1}$, i.e. the real exchange rate is fully determined by aggregate traded consumption. When the financial constraint is binding, traded consumption $c_{T, 1}$ is pinned down by the period 1 budget constraint together with the binding borrowing constraint,

$$
c_{T, 1}=y_{T, 1}+B_{1}+\phi\left(c_{T, 1}\right)
$$

\footnotetext{
${ }^{7}$ We will introduce a nominal exchange rate in the following section and discuss the relationship to the real exchange rate studied here.
} 
This fixed point equation implicitly defines a function $c_{T, 1}\left(B_{1}\right)$ and by extension $p_{N}\left(B_{1}\right)=c_{T, 1}\left(B_{1}\right)$ with slope

$$
p_{N}^{\prime}\left(B_{1}\right)=\frac{1}{1-\phi^{\prime}\left(p_{N}\right)}
$$

The consumer's value function can then be expressed as

$V^{i}\left(b_{1}^{i} ; B_{1}\right)=\max _{b_{2}^{i}} u\left(\sqrt{y_{T, 1}+b_{1}^{i}-b_{2}^{i} / R}\right)+\beta u\left(y_{T, 2}+b_{2}^{i}\right)+\lambda^{i}\left[b_{2}^{i} / R+\phi\left(p_{N}\left(B_{1}\right)\right)\right]$

Using this value function, the period 0 borrowing choices of individual consumers are described by the same Euler equation (6) as in our generic model of externalities. Since the value function satisfies $V_{b}(\cdot)=u_{T, 1}$ for individual consumers, they fully smooth traded consumption between periods 0 and 1 .

We analyze the problem of a constrained planner in the spirit of Stiglitz (1982) to analyze the constrained efficiency of the borrowing decisions of individual consumers. In other words, we ask if a planner (or policymaker) who is subject to the same financial constraint as individual consumers would choose the same allocation. This reflects the problem faced by financial regulators who can regulate individual borrowing decisions but cannot lift the constraints that the market imposes on individuals for incentive, selection, or enforcement reasons. In other words, in an environment with financial constraints, it would be an unfair exercise to compare the allocations of constrained consumers with the first-best allocations that could be obtained by a planner who does not face any financial constraints. In the given setup, the problem of the constrained planner also coincides with that of a Ramsey planner who is restricted to a single instrument - a tax that allows her to intervene in the borrowing choices of individual consumers.

Formally, the period 1 problem of the constrained planner is to solve problem (21) while internalizing that aggregate allocations coincide with the allocations chosen by individual agents, $B_{1}=b_{1}^{i}$ etc. In period 0 , this gives rise to the same Euler equation (8) as that of the planner in the previous section. However, the envelope condition of the constrained planner is modified - she internalizes that there is an additional effect from borrowing, which reflects a pecuniary externality and is captured by

$$
V_{B}(\cdot)=\lambda \phi^{\prime}\left(p_{N}\right) \cdot p_{N}^{\prime}\left(B_{1}\right)
$$

Intuitively, a marginal increase in the country's aggregate bond holdings in period 0 (i.e. a reduction in borrowing) increases domestic traded consumption in period 1, which appreciates the real exchange rate by $p_{N}^{\prime}$ and relaxes the constraint by $\phi^{\prime}$ which has shadow value $\lambda=u_{T, 1}-u^{\prime}\left(c_{T, 2}\right)$ for the representative consumer. When the constraint is binding so $\lambda>0$, the externality term is positive $V_{B}(\cdot)>0$. In short, less borrowing in period 0 mitigates the balance sheet effects and financial amplification dynamics in period 1.

Following equations (11) and (14), the policymaker can restore constrained efficiency by imposing a quantity limit on borrowing or a tax that reflects the 
magnitude of the externality in period 0 ,

$$
\tau=\frac{\lambda \phi^{\prime}\left(p_{N}\right) \cdot p_{N}^{\prime}\left(B_{1}\right)}{u^{\prime}\left(c_{T, 0}\right)}
$$

Literature A rich body of literature has employed models of balance sheet effects and financial amplification to capture emerging market financial crises. Aside from Krugman (1999a), Aghion, Bacchetta, and Banerjee (2000, 2001), Céspedes, Chang, and Velasco (2004) and Mendoza (2010) also develop influential emerging market models of balance sheet effects. ${ }^{8}$ Chang and Velasco (2000a, 2000b, 2001) develop crisis models based on financial fragility and runs, in which the exchange rate also plays an important role.

Following this body of work, a growing number of papers have investigated the normative implications of financial crises that involve balance sheet effects, as illustrated in our simple model above, focusing on pecuniary externalities. The central insight of this literature is that private agents do not internalize how their joint behavior affects market prices such as exchange rates or asset prices, which interact with financial constraints. As a result, individual private agents impose externalities on each other. The externalities are pecuniary externalities since they occur via movements in market prices such as asset prices and exchange rates. In a standard Arrow-Debreu model with complete markets, the first welfare theorem tells us that pecuniary externalities do not matter for Pareto efficiency because price changes simply generate wealth effects that are equivalent to lump sum transfers across agents. However, when financial markets are imperfect, e.g. due to balance sheet effects, pecuniary externalities generally lead to constrained Pareto inefficient outcomes, i.e. a constrained social planner or policymaker who takes the financial market imperfections as given, can coordinate the behavior of private agents in a way that generates a Pareto improvement. ${ }^{9}$

Dávila and Korinek (2018) distinguish pecuniary externalities in economies with financial imperfections into two categories:

First, distributive pecuniary externalities arise when risk-sharing is incomplete and a planner can affect market prices in a way that achieves a wealth redistribution between agents that improves risk-sharing. For example, Caballero and Krishnamurthy (2003) and Lorenzoni (2008) show that a planner who restricts dollar borrowing or leverage, respectively, mitigates exchange rate and

\footnotetext{
${ }^{8}$ In the context of traditional macroeconomics, this type of adverse feedback mechanism between prices and financial constraints has long been recognized, dating back to Fisher (1933)'s description of debt deflation during the Great Depression, and including formal models by Bernanke and Gertler (1985, 1989), Kiyotaki and Moore (1997) and Bernanke, Gertler, and Gilchrist (1999) under the term financial accelerator or financial amplification.

${ }^{9}$ The general insight that pecuniary externalities may lead to constrained Pareto inefficient outcomes has been observed e.g. by Hart (1975), Stiglitz (1982), Greenwald and Stiglitz (1986), and Geanakoplos and Polemarchakis (1986). However, in principle, the pecuniary externalities could go in either direction, as emphasized e.g. by Dávila and Korinek (2018). One of the contributions of the body of literature on balance sheet crises and pecuniary externalities is to establish that under broad circumstances, the direction of externalities that arise during financial crises is quite predictable.
} 
asset price declines in crisis states, which improves the terms-of-trade of constrained borrowers who engage in fire sales and thereby leads to better risk-sharing between borrowers and lenders. Caballero and Lorenzoni (2014) identify distributive externalities between entrepreneurs and workers in a small open economy that create a case both for ex-ante and ex-post intervention.

Second, collateral pecuniary externalities (or, more generally, price-in-theconstraint externalities) arise when market prices such as asset prices or exchange rates show up in a binding financial constraint and a planner can engage in actions that increase the price and relax the financial constraint. This is the case in our simple example above, in which the exchange rate shows up in the financial constraint. Korinek (2007, 2011a) shows that such collateral externalities may induce emerging market borrowers to take on too much foreign currency debt. Jeanne and Korinek (2010) and Bianchi (2011) observe that they may lead to excessive borrowing in general. Korinek (2011b, 2018) demonstrates that they generate excessive risk-taking and under-insurance - flows that increase risk-sharing, such as FDI, involve negligible externalities, whereas uncontingent debt flows, especially if denominated in foreign currency, lead to substantial externalities. Benigno et al. (2013) introduce an additional decision margin, production, in a similar setting and show that it is also distorted, providing an additional policy target. Benigno et al. (2016, 2019) demonstrate that a planner can relieve the financial constraint and thus resolve any collateral pecuniary externalities if she has sufficient instruments, in particular if she can set the exchange rate to a level such that the financial constraint is slack without introducing other distortions in the economy. Importantly, these three papers study the policy options of a planner who can intervene during crises episodes, not just ex-ante before crises occur. In a model of endogenous growth, Ma (2018) finds that collateral externalities also lead to welfare losses because of excessively volatile growth.

\subsection{Recessions, Aggregate Demand Externalities, and Over- borrowing}

Another strand of literature has focused on how capital flows in open economies may generate externalities by interfering with aggregate demand management. Such aggregate demand externalities may arise whenever aggregate demand differs from aggregate supply, for example because an economy features sticky prices that give rise to non-clearing of markets (see for example, Woodford, 2004, and Galí, 2015). When markets do not clear, aggregate demand - like prices in the previous section - is an equilibrium object that individual private agents take as given. This implies that individual agents rationally do not internalize their contribution to aggregate demand, generating scope for externalities.

International capital flows may give rise to aggregate demand externalities because they reallocate spending between domestic and foreign agents who have different consumption baskets and by implication different marginal propensities to consume (MPC). Specifically, domestic agents have a higher MPC on domestic goods than foreigners. Capital inflows thus generally lead to an increase 
in domestic aggregate demand and outflows to a reduction in domestic aggregate demand. If other tools for macroeconomic management are imperfect, for example because emerging economies face limited autonomy in monetary and exchange rate policy and the use of fiscal policy is costly, then these changes in demand have real implications and generate externalities. As we will show in the following example, a constrained planner who internalizes these effects can generally improve welfare by coordinating the financial market transactions of private agents so as to improve aggregate demand management, for example by curbing borrowing and risk-taking of domestic agents during booms so as to improve domestic aggregate demand management in future periods.

Model of Aggregate Demand Externalities We extend our baseline setup by introducing non-traded goods and nominal price stickiness to study aggregate demand externalities. We assume a unit mass of domestic consumer-producers who value both traded and non-traded goods in period 1 ,

$$
\begin{aligned}
& U^{i}=u\left(c_{T, 0}^{i}\right)+\beta\left[u\left(c_{1}^{i}\right)-d\left(\ell^{i}\right)\right] \\
& \text { where } \quad c_{1}^{i}=c\left(c_{T, 1}^{i}, c_{N, 1}^{i}\right)=\sqrt{c_{T, 1}^{i} c_{N, 1}^{i}}
\end{aligned}
$$

$c_{1}^{i}$ is a period 1 consumption index that combines traded and non-traded goods as in (16), and $d\left(\ell^{i}\right)$ is a disutility term for period 1 labor effort. Consumerproducers obtain a traded goods endowment $y_{T, 1}$. The non-traded good is produced using labor $y_{N, 1}^{i}=\ell^{i}$. The first-best allocation in the economy (denoted by stars) is described by the two optimality conditions

$$
\begin{aligned}
u^{\prime}\left(c_{T, 0}^{*}\right) & =\beta u_{T, 1}\left(c_{1}^{*}\right) \\
u_{N, 1}\left(c_{1}^{*}\right) & =d^{\prime}\left(\ell^{*}\right)
\end{aligned}
$$

where we use the notation $u_{T, 1}(\cdot)=\partial u\left(c\left(c_{T, 1}, c_{N, 1}\right)\right) / \partial c_{T, 1}$ and $u_{N, 1}(\cdot)=$ $\partial u(\cdot) / \partial c_{N, 1}$. Note that this allocation could be decentralized by setting the relative price of non-traded goods in period 1 to the marginal rate of substitution (MRS) between the two goods in the first-best, $p_{N}^{*}=u_{N, 1}^{*} / u_{T, 1}^{*}=c_{T, 1}^{i *} / c_{N, 1}^{i *}$.

Aggregate Demand Effects However, to create a role for aggregate demand effects, we introduce price stickiness in the economy. We normalize the nominal prices of traded goods in both periods 0 and 1 to $P_{T}^{*} \equiv 1$ in foreign currency so they are $P_{T}=E P_{T}^{*}$ in domestic currency, where $E$ is the country's exchange rate. Furthermore, we assume that the nominal price of the non-traded good is fixed at $P_{N}=1$ because of price stickiness in period $1 .{ }^{10}$ So far these assumptions are not restrictive - if the exchange rate was flexible, the first-best

\footnotetext{
${ }^{10}$ To relate this setup to the model of pecuniary externalities in the previous section, observe that we can express our measure of the real exchange rate there as $p_{N}=P_{N} / P_{T}=P_{N} / E$; the real exchange rate is lowered by depreciations in the nominal exchange rate $E$.
} 
allocation described above can be implemented by allowing the exchange rate to move to the level that clears the market. ${ }^{11}$

However, to capture aggregate demand effects, we also assume that the exchange rate is pegged at $E=1$ in this section. Furthermore, we assume that consumer-producer $i$ cannot consume her own non-traded goods production. Instead, she agrees to produce and sell the quantity demanded at the prevailing price to a random consumer $j \neq i$ to whom she is matched. This generates a motive for agents to trade in the market for non-traded goods so that the market price and demand conditions for the good matter. ${ }^{12}$ For given demand $c_{N, 1}^{j}$ by consumer $j$, consumer-producer $i$ thus provides $\ell^{i}=c_{N, 1}^{j}$ units of labor to produce the output that is demanded. In a symmetric equilibrium, $y_{N, 1}^{i}=c_{N, 1}^{j}=c_{N, 1} \forall i, j$. In summary, whenever relative prices do not correspond to the first-best MRS, the production of non-traded goods adjusts to re-equilibrate the economy.

The optimization problem of consumer $i$ is

$$
\begin{gathered}
\max _{b^{i}, c_{T, 1}^{i}, c_{N, 1}^{i}} u\left(y_{T, 0}-\frac{b^{i}}{R}\right)+\beta\left[u\left(\sqrt{c_{T, 1}^{i} \cdot c_{N, 1}^{i}}\right)-d\left(\ell^{i}\right)\right] \\
\text { s.t. } P_{T} c_{T, 1}^{i}+P_{N} c_{N, 1}^{i}=P_{T}\left(y_{T, 1}^{i}+b^{i}\right)+P_{N} y_{N, 1}^{i} \\
y_{N, 1}^{i}=\ell^{i}=c_{N, 1}
\end{gathered}
$$

The last equality in the third line captures our assumptions on how the market equilibrates. The budget constraint (24) is equivalent to constraint (17) multiplied by the nominal price of traded goods $P_{T}=E$. We combine consumer $i$ 's optimality conditions on traded and non-traded consumption to find

$$
\frac{c_{T, 1}^{i}}{c_{N, 1}^{i}}=\frac{P_{N}}{P_{T}}
$$

Since $P_{N}=P_{T}$ due to price stickiness, consumers demand traded and nontraded goods in equal proportion. In a symmetric equilibrium, the non-traded output of consumer-producer $i$ is determined by aggregate demand for nontraded goods, which in turn equals aggregate traded consumption, $y_{N, 1}^{i}=$ $c_{N, 1}=c_{T, 1}$. Dropping non-traded consumption and production from the period 1 budget constraint, we further find that aggregate traded consumption is $c_{T, 1}=y_{T, 1}+B$. In combination,

$$
c_{N, 1}=c_{T, 1}=y_{T, 1}+B
$$

\footnotetext{
${ }^{11}$ The New Keynesian literature typically assumes that prices are set optimally but subject to certain adjustment frictions that generate suboptimal relative prices. For expositional simplicity, we simply assume that prices are fixed here.

${ }^{12}$ Much of the New Keynesian literature generates a motive for agents to trade by assuming - in similar fashion, but generating significant additional notation - that there is a continuum of intermediate goods producers who agree to sell any quantity demanded at prevailing prices, and that these intermediate goods are combined using a Dixit-Stiglitz production function to yield a final good. The substantive insights are the same.
} 
Price stickiness implies that the demand for non-traded goods depends on consumers' traded endowment and bond holdings. In an economy with flexible prices, an increase in the traded income of the consumers in the economy (for example because of higher aggregate bond holdings $B$ ) would imply an increase in the relative price of nontraded goods. However, since prices are sticky, it implies an increase in the demand for nontraded goods in our setup.

An individual consumer-producer $i$ who faces aggregate demand for nontraded goods (26) and solves the optimization problem (23) consumes

$$
c_{T, 1}^{i}=c_{N, 1}^{i}=\frac{y_{T, 1}+b^{i}+c_{N, 1}}{2}=y_{T, 1}+\frac{b^{i}+B}{2}
$$

Intuitively, half of her income derives from the traded endowment plus her individual bond holdings; the other half derives from nontraded production, which is demand-determined and depends on aggregate bond holdings.

Welfare Analysis We note that a consumer-producer $i$ facing nontraded demand $c_{N, 1}$ supplies labor $\ell^{i}=c_{N, 1}$. Furthermore, for allocations with symmetric traded/non-traded consumption, we can simplify notation so $c_{T, 1}^{i}=c_{N, 1}^{i}=c_{1}^{i}$ and $u_{T, 1}=u_{N, 1}=u^{\prime}\left(c_{1}^{i}\right) / 2$.

We then write the period 1 value function of consumer-producer $i$ as

$$
V\left(b^{i} ; B\right)=u\left(y_{T, 1}+\frac{b^{i}+B}{2}\right)-d\left(y_{T, 1}+B\right)
$$

The resulting Euler equation for bond holdings is, in analogy to our baseline model,

$$
u^{\prime}\left(c_{0, T}\right)=\beta R V_{b}=u_{T, 1}\left(c_{1}\right)
$$

Individual consumer-producers rationally take aggregate demand as given. A planner who can affect the savings decisions of consumers, by contrast, internalizes that her savings decisions affect aggregate demand for non-traded goods, given that prices are sticky. The effect of an increase in aggregate bond holdings that is not internalized by individual consumers can be expressed as

$$
V_{B}=u_{N, 1}\left(c_{1}\right)-d^{\prime}(\ell)
$$

This expression is commonly referred to as a measure of the labor wedge - it represents the difference between the marginal benefit of producing one more unit of nontraded output and the marginal cost of the labor required. It can also be interpreted as the marginal contribution of aggregate bond holdings to the output gap. In an efficient allocation (e.g. if prices were flexible), the labor wedge is zero, and there are no uninternalized effects of consumers' foreign savings decisions on the market for nontraded goods. This applies e.g. to the first-best described in (22). By contrast, when prices are sticky, if there is a demand shortage for non-traded goods $u_{N, 1}\left(c_{1}\right)>d^{\prime}(\ell)$, greater foreign bond holdings would lead to higher traded consumption, raise demand for non-traded goods and increase welfare; if there is excess demand for non-traded goods 
$u_{N, 1}\left(c_{1}\right)<d^{\prime}(\ell)$, a reduction in foreign bond holdings would lower traded consumption and lower demand for non-traded goods so as to increase welfare.

More formally, the planner's maximization problem is given by problem (7). The resulting Euler equation is

$$
u^{\prime}\left(c_{0}\right)=\beta R\left[V_{b}(B ; B)+V_{B}(B ; B)\right]=u_{T, 1}\left(c_{1}\right)+u_{N, 1}\left(c_{1}\right)-d^{\prime}(\ell)
$$

Using formula (14), the planner can correct the externality and restore an efficient allocation by imposing the capital control

$$
\tau=\frac{u_{N, 1}\left(c_{1}\right)-d^{\prime}(\ell)}{u^{\prime}\left(c_{0}\right)}
$$

or an equivalent quantity regulation. If there is a demand shortage in period 1 , then the labor wedge is positive and $\tau>0$ so the planner taxes borrowing (subsidizes saving) in period 0; if there is excess demand in period 1 , the planner subsidizes borrowing (taxes saving) in period 0 so as to reduce overheating.

Notice that it is generally not optimal for the planner to fully eliminate the labor wedge as intervening in the borrowing/saving decision of consumerproducers creates an intertemporal distortion. The planner chooses the point where the marginal cost of this intertemporal distortion equals the marginal benefit of reducing the distortion in the labor wedge. We noted earlier that a simple way to avoid aggregate demand imbalances and the associated externalities in our simple model is to let the exchange rate adjust. For example, if a capital outflow in period 1 reduces demand for non-traded goods in parallel with the lower availability of traded goods, then an exchange rate depreciation would make non-traded goods cheaper and close the labor wedge. However, in a fuller model, such exchange rate depreciations frequently cause a separate set of problems for emerging economies arising from the pecuniary externalities that we covered earlier.

Related Literature Farhi and Werning (2012, 2014) show that restrictions on monetary and exchange rate policy in an open economy with sticky prices create aggregate demand externalities and a case for capital controls as secondbest instruments to manage demand, similar to our simple example above. However, they observe that even with flexible exchange rates, there is a case for capital controls when monetary policy alone cannot optimally manage the sectoral composition of demand. Similarly, Schmitt-Grohé and Uribe (2016) show that fixed exchange rates and nominal wage stickiness give rise to aggregate demand externalities that may motivate capital controls. Korinek and Simsek (2016) demonstrate that a binding zero-lower bound that restricts monetary policy creates a case for financial market taxes to address the resulting aggregate demand externalities. Farhi and Werning (2016) lay out a general theory of aggregate demand externalities that emphasizes that such externalities arise whenever aggregate demand management is imperfect and financial market interventions can contribute to demand management in a second-best manner. 
Policymakers often face a difficult trade-off in managing the two problems that we have described in the past two sections, i.e. adverse balance sheet effects and aggregate demand problems. The use of fiscal policy is frequently constrained in emerging economies, particularly during crises. Many other expost policy measures affect balance sheets and aggregate demand in opposite directions, creating a difficult trade-off. For example, policymakers frequently use interest rate hikes during periods of capital outflows to reduce the outflows and counteract exchange rate depreciations so as to mitigate balance sheet effects, but higher interest rates also reduce aggregate demand, worsening the resulting contraction of output. This trade-off is frequently one of the main points of contention in the policy debate on how to respond to financial crises (see e.g. Stiglitz, 2002). In turn, during booms, policymakers may be induced to reduce interest rates so as to reduce capital inflows and associated aggregate demand effects.

More generally, procyclical capital flows reduce the space to adopt countercyclical macroeconomic policies, and may actually lead authorities to adopt procyclical macroeconomic policies (Ocampo, 2008). From an ex-post perspective, the trade-off is analyzed in Lahiri and Végh (2003). The use of capital controls can mitigate this trade-off by addressing both pecuniary and aggregate demand externalities ex-ante, as shown for example by Farhi and Werning (2016) in Application 3 of their paper in a framework that integrates aggregate demand problems and a price-dependent collateral constraint.

\subsection{Other Categories of Distortions and Externalities}

Although the recent economic literature to motivate capital controls has been most active on the topic of pecuniary and aggregate demand externalities as exposed in the past two subsections, we should also mention two further categories of potential distortions generated by international capital flows.

Moral Hazard and Bailouts A recurrent theme in the literature is that borrowers may engage in excessive borrowing because they expect that they will not have to repay their full debts in the event of crisis because of bailouts. To capture this analytically, we return to our baseline setup from section 1.1 and assume consumers are borrowers, $b^{i}<0$, who are subject to imperfect contract enforcement coupled with debt bailouts. Specifically, let us focus on a single state of nature in which consumer $i$ reneges on a fraction $\alpha$ of her repayments to international lenders, but the government of the small open economy bails out international lenders and makes them whole for their credit losses. Since lenders do not suffer any losses, they provide funds at the risk-free interest rate $R$, and the period 0 budget constraint (1) is unchanged. The government finances the bailout by a lump-sum tax $T=\alpha B<0$ in period 1 where $B$ is again aggregate borrowing. The period 1 budget constraint of consumer $i$ is then

$$
c_{1}^{i}=y_{T, 1}+(1-\alpha) b^{i}+T
$$


and the period 1 continuation utility is

$$
V\left(b^{i} ; B\right)=u\left(y_{T, 1}+(1-\alpha) b^{i}+\alpha B\right)
$$

Given this value function, observe that the Euler equations (6) and (8) of both private agents and the social planner continue to hold. Under bailouts, the envelope condition $V_{b}(\cdot)=(1-\alpha) u^{\prime}(\cdot)$ reflects that private agents internalize only a fraction $(1-\alpha)$ of their cost of repayment, whereas the externality term $V_{B}(\cdot)=\alpha u^{\prime}(\cdot)$ reflects the remaining social cost that arises because borrowing increases the tax revenue needed for bailouts.

The argument that bailouts expectations create moral hazard and induce greater leverage and risk-taking is regularly advanced to explain financial booms and busts. For example, McKinnon and Pill $(1997,1998)$ provide models of financial booms and overborrowing due to moral hazard, and Krugman (1999b) analyzes whether the East Asian crisis can be understood through that lens. However, although models of moral hazard provide an account of both the large risk-taking in booms and the frequently sizeable bailouts in busts, thereby generating a coherent narrative of crisis, they assign perhaps too much foresightedness and rationality to the agents taking on risk in financial booms. For example, in the context of the mortage boom before the US financial crisis of 2008-09, Cheng, Raina, and Xiong (2014) show that many of the actors who exposed the financial sector to large risks took on even greater risks in their personal investments, for which bailouts were highly unlikely. This suggests that their behavior was driven more by over-optimism rather than bailout expectations.

Over-Optimism If borrowers are overly optimistic about future economic prospects, they naturally tend to borrow more than what is optimal under more realistic prospects. The welfare implications of such over-optimism are two-fold: First, over-optimism reduces the realized welfare of the borrower who takes on too much debt compared to what would be optimal under realistic expectations; we may call this an internality rather than an externality because the borrower imposes this welfare loss on herself due to her unrealistic expectations. Second, over-optimism exacerbates any other externalities from borrowing that may be present in the economy, including the externalities laid out in the previous sections, because it induces individuals to borrow even more. Similar implications result from other, related behavioral biases, e.g. myopic preferences as proposed by Laibson (1997). Boz (2009) shows that over-optimism (and over-pessimism) in emerging economies may arise from a signal extraction problem.

To capture over-optimism in a simple analytic setting, let us extend the baseline setup from section 1.1 by assuming that consumers are overly optimistic and expect a period-1 endowment that is greater than the actual endowment they will receive, $\tilde{y}_{T, 1}>y_{T, 1} \cdot{ }^{13}$ Private agents will optimally smooth consump-

\footnotetext{
${ }^{13}$ An alternative way of capturing over-optimism is to assume that agents over-value the probability of states of nature with good outcomes and undervalue the probability of states of nature with bad outcomes. See e.g. section 5 of Korinek (2018) for such a setting in the context of capital controls.
} 
tion from their optimistic perspective so $u^{\prime}\left(c_{0}^{i}\right)=\beta R V_{b}(\cdot)=\beta R u^{\prime}\left(\tilde{c}_{1}^{i}\right)$ where $\tilde{c}_{1}^{i}=\tilde{y}_{T, 1}+b^{i}$ reflects the inflated level of consumption that consumers expect due to their over-optimism. Naturally, when the true endowment $y_{T, 1}$ is realized in period 1 , the resulting allocation will satisfy $u^{\prime}\left(c_{1}^{i}\right)>u^{\prime}\left(\tilde{c}_{1}^{i}\right)$, i.e. the marginal utility of consumers will be higher than they anticipated. A policymaker who is non-paternalistic, i.e. who takes the preferences and beliefs of consumers as given, will not find any reason to intervene in the resulting allocation. By contrast, a paternalistic policymaker who knows the true realization of $y_{T, 1}$, would disagree with the overly optimistic choices of individual consumers and would choose a lower level of borrowing (higher bond holdings) that instead leads to an allocation such that $u^{\prime}\left(C_{0}\right)=\beta R u^{\prime}\left(C_{1}\right)<\beta R u^{\prime}\left(c_{1}^{i}\right)$, where upper-case variables denote the planner's choices. We capture the internality by defining the term $V_{B} \equiv \beta R\left[u^{\prime}\left(C_{1}\right)-u^{\prime}\left(\tilde{C}_{1}\right)\right]>0$, where $\tilde{C}_{1}=\tilde{y}_{T, 1}+B$ is the consumption level anticipated by overly optimistic consumers under the planner's choice of $B$. Note that $\tilde{C}_{1}>\tilde{c}_{1}^{i}$ since the planner chooses less debt, i.e. higher bond holdings $B>b^{i}$. The term $V_{B}$ simply reflects the difference between the true and the overly optimistic marginal utility of consumers. Under this definition, the optimal tax formula (14) continues to hold for the case of regulating internalities from overborrowing due to over-optimism.

A significant challenge for policy is that phenomena such as over-optimism are difficult to ascertain in practice. For example, it is common for regulators and policymakers to become infected by the same optimism that drives individual market participants during booms. Furthermore, when policymakers and private agents disagree because policymakers overly pessimistic, paternalistic regulation to reduce borrowing would be welfare-reducing. These are examples of the conceptual problems in advocating paternalism. For these reasons, policymakers are justifiably more hesitant to respond to internalities, such as those from over-optimism, than to respond to externalities, such as those that we analyzed earlier. ${ }^{14}$ However, even a non-paternalistic policymaker will tighten regulation when over-optimism leads private borrowers to borrow more and thereby impose greater externalities on others. Section 5 of Korinek (2018) provides a careful analysis of this case.

\section{Measurement and Effectiveness of Capital Con- trols}

This section examines the classification and measurement of capital controls as well as the empirical evidence on how effective capital controls are in reducing financial and macroeconomic fragility. Relating the theories of capital controls we laid out to empirical evidence requires that we first discuss the different varieties of capital controls observed in practice. Then we describe the context in which emerging and developing countries experience boom-bust cycles in ca-

\footnotetext{
${ }^{14}$ For a careful discussion of liberalism versus paternalism and solutions to the resulting tension in policymaking, see e.g. Sunstein and Thaler (2003).
} 
pital flows and use capital controls as a tool to manage these cycles. Next we analyze how different measures of capital controls capture different aspects of capital account openness. We also examine the channels through which capital controls affect the economy, distinguishing between direct effects as well as signaling and expectations effects. Then we review the empirical literature on how capital controls affect (i) financial fragility outcomes including domestic credit growth, composition and maturity of external liabilities, and other vulnerabilities associated with sudden stops in capital inflows, and (ii) macroeconomic outcomes such as long-term economic growth, short-term output and consumption volatility, and exchange rate fluctuations. We describe literature focusing on both aggregate macroeconomic variables and firm-level variables. We also focus on differences in capital control measures and empirical methodologies that give rise to differences in findings for each set of outcomes, and we highlight the strengths and pitfalls of different empirical approaches and draw conclusions for promising venues for future research.

\subsection{Varieties of Capital Controls}

Whereas capital controls in theoretical models can be expressed as elegant tax wedges or quantity limits, the practical implementation of capital controls is considerably more complex and depends significantly on institutional details. In practice, capital controls can be categorized along a number of dimensions:

First, capital controls can be distinguished depending on what they are imposed on, as we have already seen in section 1.2. An important dimension of this is the direction of capital flows, i.e. whether controls are placed on inflows or outflows of capital. A second important dimension is which type of private capital account transactions they are imposed on, for example FDI, portfolio investment into equities or bonds, or other investments which include bank loans and other banking flows. In the context of bonds and loans, an important aspect is whether controls distinguish between foreign and local currency and short-term versus long-term flows.

Second, another distinction is whether capital controls are price-based, i.e. taxes or subsidies on capital flows, or quantitative or administrative restrictions, such as outright prohibitions or quantity limits on transactions in certain asset categories. Generally speaking, the principle of dualism, already noted in section 1.2 , implies that every quantity-based control corresponds to an equivalent pricebased control. In practice, the equivalence does not hold when the agents subject to controls are heterogeneous or when there is uncertainty about the parameters of the economy (see Weitzman, 1974).

Third, capital controls are also distinguished by the timing of controls with regard to the objective of reducing financial and macroeconomic instability, i.e. whether controls are imposed ex-ante or ex-post with respect to such instability. Ex-ante capital controls are prudential tools that reduce the risk of financial crises by preventing excessive risk-taking. Examples include tightening of controls that aim to reduce capital inflows during booms and reductions in outflow controls that encourage outflows during booms to reduce overheating pressu- 


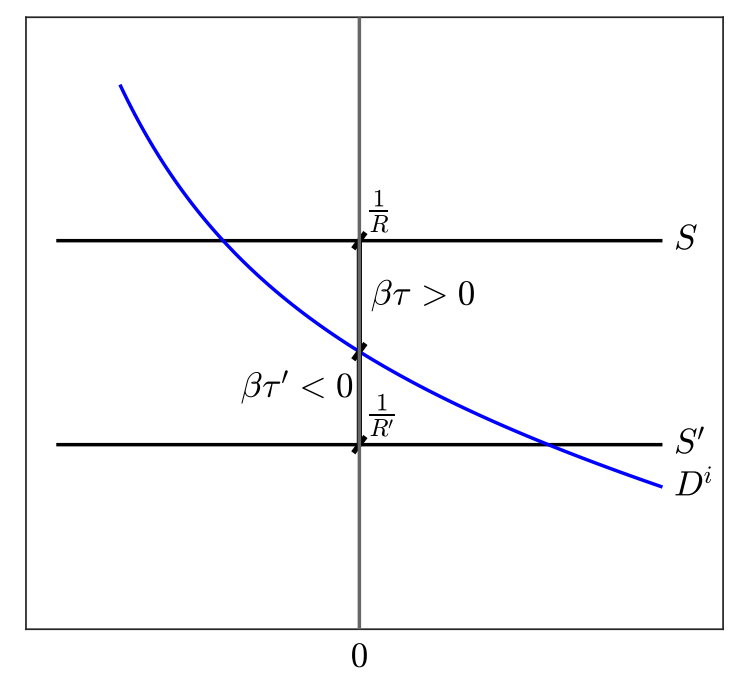

Figure 2: Fixed quantity-based controls equal counter-cyclical price-based controls

res. ${ }^{15}$ Capital inflow and outflow controls may also be used as ex-post interventions once a crisis occurs. For example, measures that encourage new borrowing from abroad by reducing capital inflow regulations are ex-post interventions that may increase the availability of credit after a crisis. Similarly, putting in place or tightening capital outflow controls once a crisis has materialized may halt a self-reinforcing feedback cycle of capital outflows and exchange rate depreciations when complemented with responsible macroeconomic policies (Saborowski et al., 2014). Prior to the 2008-09 Global Financial Crisis, the dominant view was that the best time to intervene was ex post, after a crisis has occurred, as opposed to in the run up to a crisis when fragility builds up, as suggested e.g. by the "Greenspan doctrine." However, Jeanne and Korinek (2013, 2019) and Benigno et al. (2016) show it is optimal to use a mix of ex-ante prudential regulations and ex-post policies to minimize the welfare costs of financial and macroeconomic instability, since ex-post policy interventions generally impose deadweight losses on their own and may distort ex-ante incentives.

Fourth, capital controls are sometimes distinguished into structural (or longstanding) capital controls that are typically in place for a long time, versus cyclical (or episodic) capital controls that are regularly adjusted over the business cycle (see e.g. Klein, 2012). Structural controls typically take the form of quantity-based controls, whereas cyclical controls frequently take the form of price-based controls. Interestingly, this implies that the difference between the

\footnotetext{
${ }^{15}$ For example, several emerging market economies, including Brazil and Korea, have increased or implemented new capital inflow controls in response to the surge in capital inflows in 2009. South Africa has liberalized its capital outflow controls during the same period (Baba and Kokenyne, 2011).
} 
two types of controls may be smaller than what is commonly appreciated: fixed quantity controls are equivalent to counter-cyclical price-based controls, given that capital flows to emerging economies are generally pro-cyclical. Figure 2 illustrates this for the case of a closed capital account, equivalent to the quantity restriction $B=0$. Assume that the supply of foreign funds fluctuates over the cycle and is high during booms (indicated by the $S$-curve and the low interest rate $\frac{1}{R}$ ) and low during busts (indicated by the $S^{\prime}$-curve and the high interest rate $\frac{1}{R^{\prime}}$, where $R^{\prime}>R$ ). During booms, the zero quantity restriction is equivalent to a positive inflow $\operatorname{tax}(\beta \tau>0)$, i.e. consumers that are taxed precisely at the rate $\beta \tau$ indicated in the figure would be willing to hold zero bonds. This prevents any excessive borrowing that would otherwise take place during booms. Conversely, during busts, as the supply of available foreign funds declines to $S^{\prime}$, the zero quantity restriction on international capital flows is equivalent to an outflow $\operatorname{tax}\left(\beta \tau^{\prime}<0\right)$, reducing the outflow of capital that would otherwise take place. Hence, fixed quantity controls are de facto equivalent to price controls that are adjusted counter-cyclically over the course of the business cycle.

Finally, another important distinction is whether a policy measure is an explicit capital control directly imposed on cross-border transactions or whether it is a domestic regulation that restricts the financial transactions of domestic agents or the domestic use of foreign currency. Although the latter type of regulations are not notionally aimed at international capital flows, they have a de facto effect of influencing the level of such flows. Ocampo (2017, ch. 4) observes that there is a continuum of financial regulations that begins with regulations on financial transactions by domestic residents in the domestic currency (traditional prudential regulation, including counter-cyclical macroprudential regulations). Next there are restrictions on the domestic use of foreign currency by domestic residents (FX-related regulations ${ }^{16}$ ), which do not officially count as capital controls but have the side effect of applying to most transactions with foreigners who typically transact in foreign currency. Finally there are restrictions on domestic agents' transactions with foreign residents, which we will refer to as "financial sector regulations" below, for example limits on residents' capacity to borrow and hold accounts abroad, as well as on the capacity of non-residents to hold domestic accounts - these discriminate between residents and non-residents and therefore officially count as capital controls.

From a theory perspective, Korinek and Sandri (2016) argue that the concurrent use of both capital controls and domestic macroprudential policy is desirable: the two policies target two different kinds of problems, excessive foreign credit versus excessive credit at large. They may be complementary or may be used as substitutes, depending on the source of credit expansion. However, in countries that have completely liberalized their capital accounts or signed agreements (such as bilateral investment treaties with the US or membership

\footnotetext{
${ }^{16}$ These include outright prohibitions of certain domestic transactions in foreign currencies, restrictions on what lending can be done locally in foreign currencies or what securities can be issued denominated in foreign currencies, differential treatment (e.g., differential reserve requirements) on deposit accounts in foreign currencies, and limits on the foreign exchange positions of financial intermediaries.
} 
agreement of EU) that prohibit the use of explicit capital controls, domestic prudential regulation typically plays an important role as a second-best instrument in lieu of direct capital controls. In such cases, even simple countercyclical regulations of bank leverage, such as those advocated by Admati and Hellwig (2013), may have an important effect on the magnitude of international capital flows. For example, Schmitt-Grohé and Uribe (2016) argue that tighter bank regulations in the periphery of the Eurozone during the run-up to the 2008/09 financial crisis would have mitigated the severity of the Euro crisis.

\subsection{Capital Flow Volatility}

Figure 3 shows that net capital flows to emerging and developing countries have been large and volatile, following a pattern of boom-bust cycles. These cycles pose several challenges for countries and may generate significant externalities, as we highlighted in the theory section, especially in countries with less developed financial markets. During capital flow surges, countries experience currency appreciations, associated declines in competitiveness, increases in trade deficits, higher inflation, and bubbles in housing and stock markets. When external financing dries up, during what Calvo (1998) termed episodes of "sudden stops" of capital flows, other challenges emerge, including currency depreciation and associated balance sheet effects and inflationary pressures, slower economic growth, and a burst of asset price bubbles.

Since the 1990s, Figure 3 shows that emerging and developing countries have experienced three major boom-bust cycles in external financing. The first one started in the early 1990s and came to an end with the 1997-98 East Asian Financial Crisis. This phase of expansion in capital flows to emerging markets was briefly interrupted by the Mexican peso crisis in 1994. The East Asian Financial Crisis that began in Thailand in 1997 spread to other East Asian economies (including Indonesia, Malaysia, and Korea), Russia, Latin America (notably Argentina and Brazil), and Turkey. The second cycle of expansion began in 2003, shortly after the dot-com crisis in the US as the Fed began to reduce interest rates, and ended in 2007 with the subprime mortgage market crisis in US, which in turn was the beginning of the Global Financial Crisis. As Figure 3 shows, the net capital inflows of emerging and developing countries reached a record high of more than 3.5 percent of GDP. The ensuing downturn phase lasted only a few years, with most developing countries experiencing the largest outflows in 2008-09.

The third cycle began in 2010 as the expansionary monetary policies in the US and other advanced countries triggered another boom of capital flows into emerging and developing economies. The beginning of the downturn took place with the tapering of quantitative easing policy of the Fed in 2013. The contraction in capital flows continued as the super-cycle of commodity prices ended in 2014 and a number of negative developments in China's capital markets resulted in large outflows from China beginning in 2015 (Ocampo, 2017). Although there was a slight uptick in 2016-17, recent indicators of net capital flows to the developing world generally indicate that the contraction phase continued 


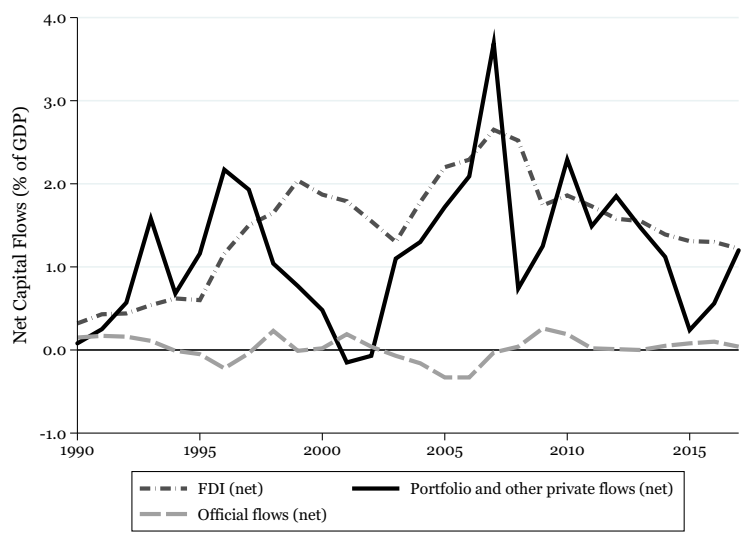

Figure 3: Capital flows to emerging and developing countries (as \% of GDP) Source: Authors' calculations based on data from the Institute of International Finance

in 2018 and 2019, given higher US interest rates, and a number of emerging economies (notably Argentina and Turkey) experienced capital outflows, strong depreciation pressures, and weak economic performance.

In response to such large and volatile capital flows, policymakers often seek policy tools that can help to manage them effectively. In general, countries adopt a combination of macroeconomic policies to tackle the challenges posed by capital flow volatility. During capital inflow surges, for instance, they may adjust interest rates, tighten fiscal policy, allow exchange rates to appreciate, accumulate foreign exchange reserves, and encourage capital outflows. However, each of these policy responses have significant limitations and costs. For example, lowering interest rates is a procyclical policy response that may cause overheating and inflation (although mitigated by exchange rate appreciation); tightening fiscal policy may result in currency appreciation and face political hurdles; allowing exchange rate to appreciate may hurt competitiveness and lead to Dutch disease; reserve accumulation may have a high fiscal cost and result in an inefficient allocation of resources; and encouraging capital outflows may have limited impact. These limitations and costs have generated a major rethinking of alternative strategies in the aftermath of the Global Financial Crisis, including a reconsideration of capital controls and domestic prudential regulations as macroprudential policy tools (Ostry et al. 2011b; Ghosh, Ostry, and Qureshi, 2017b).

\subsection{Measuring Capital Controls}

To evaluate whether the use of capital controls in a counter-cyclical fashion can be an effective policy tool in managing capital flows, the first step is to measure the strength of capital controls. One of the major challenges facing empirical work on this issue is how to represent the controls used in practice as a nume- 
rical measure that can be comparable across countries and over time. As we have seen, the variety of capital account regulations that are used in practice is broad, and countries differ strongly in the types of controls they implement (for instance, some impose quantity limits whereas others use taxes on capital flows) and the types of flows they impose controls on (such as debt or equity flows) or except entirely (FDI). The enforcement of regulations also varies across countries and may depend on what other prudential policies are used as well as on the depth of the country's domestic financial market. These problems in constructing reliable measures that do not suffer from systematic measurement error have posed significant limitations on empirical studies aiming to document robust effects of capital controls. As we discuss below, the differences in measurement continue to play a major factor in explaining why studies reach different conclusions for testing the effectiveness of capital controls. In recent years, however, various new measures have been constructed with the goal of better quantifying the restrictiveness of different capital control policies.

Measures of capital controls can be classified into two categories: (i) de jure capital control measures, which are based on the formal rules regulating capital flows that are implemented by central banks and differ based on coverage of different asset classes (Chinn and Ito, 2006; Schindler, 2009; Ostry et al., 2011a, 2011b, 2012; Fernández et al., 2016), and (ii) de facto capital control measures, which are derived from the financial outcomes that result from the use of capital controls - e.g. the deviation from covered interest rate parity, or sum of gross foreign assets and liabilities as a share of domestic output (Hutchison, Pasricha, and Singh, 2012; Rodrik and Subramanian, 2009). Since the de facto measures of capital controls are an outcome of the interactions of policy changes with market forces, most empirical studies employ de jure measures to capture policy changes in a more exogenous manner.

Figure 4 plots the evolution of capital account openness over the past half century as measured by two widely-used indices developed by (a) Quinn (1997) and (b) Chinn and Ito (2006, 2008), updated to cover the time period 1970-2015 for 187 and 182 countries respectively. Quinn used the summary information in the pre-1996 volumes of the IMF's Annual Report on Exchange Arrangements and Exchange Restrictions (AREAER) database to capture broad on/off usage of capital controls, supplemented by descriptions of these policy measures to capture their intensity. The updated index ranges from 0 to 100 , with larger values indicating more open capital accounts. The Chinn-Ito index shows the first principal component of the four sets of variables from the IMF's AREAER database, capturing not only restrictions on the capital account but also on current account transactions, the presence of multiple exchange rates, and the requirements of surrendering export proceeds. Panels (a) and (b) of the figure present the annual averages of the Quinn and Chinn-Ito indices for countries of different income groups. ${ }^{17}$

\footnotetext{
${ }^{17}$ We classified countries into three categories: (i) advanced (or industrialized) countries as the traditional OECD countries, (ii) emerging market economies, which were classified as either emerging or frontier during the period of 1980-1997 by the International Financial Corporation plus Hong Kong and Singapore, and (iii) developing countries, which are the
} 
(a) Quinn Index

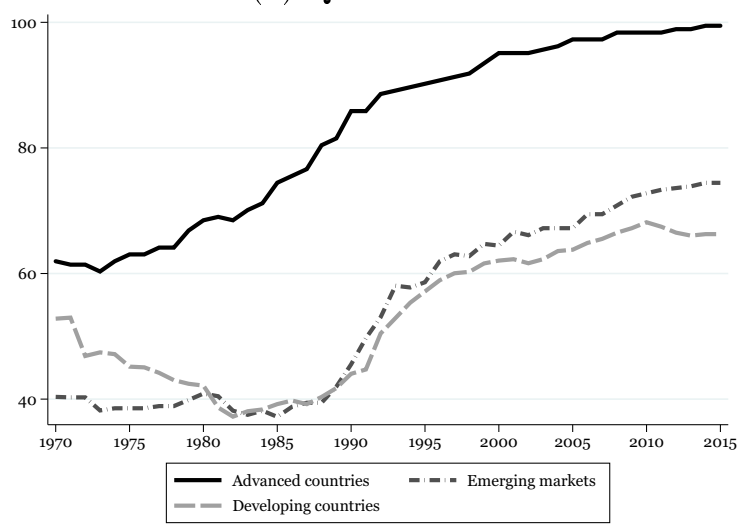

(b) Chinn-Ito Index

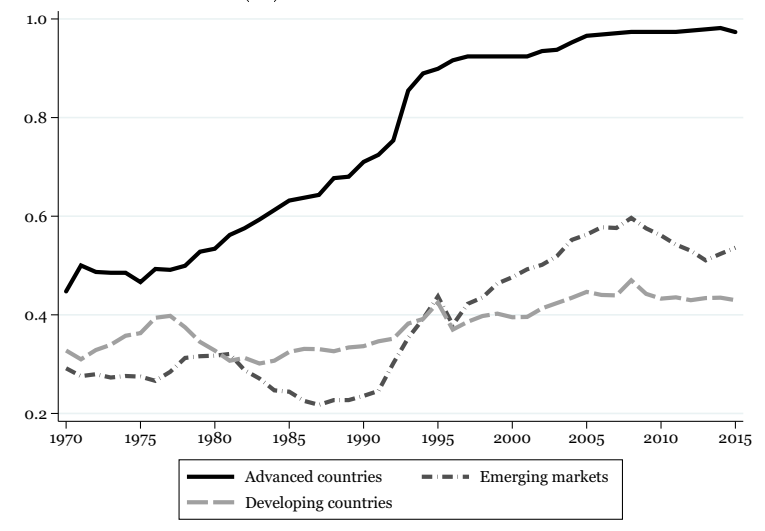

Figure 4: Indices of capital account openness, 1970 - 2015

Sources: Quinn (1997) and Chinn and Ito (2006) as well as updated data provided by Dennis Quinn and from http://web.pdx.edu/ ito/Chinn-Ito_website.htm 
On average, advanced countries steadily liberalized their capital controls, particularly from the mid-1970s to the early 1990s, and continued to maintain a high degree of capital account openness through 2015. In contrast, capital account liberalization was less widespread and slower in the emerging markets and developing countries. Although a number of emerging and developing countries had taken steps to liberalize their restrictions on capital flows in the late 1970s, the experience of the Latin American debt crisis in the 1980s led to a reversal in capital account openness as several countries reinforced their regulations. Moreover, during the 1980s, emerging market economies were perhaps less open to capital flows than the rest of the developing countries; however, they liberalized at a rapid pace and clearly surpassed developing countries in the 1990s. The increased capital account openness across the emerging and developing world continued until the 2008-09 Global Financial Crisis, after which there has been a slowdown and reversal in some countries - particularly in emerging market economies that increased their restrictions on capital flows again. Despite overall trends toward liberalization, there still remains a substantial difference in the degree to which advanced and emerging/developing countries are open to cross-border capital flows. The Quinn and Chinn-Ito indices have great coverage in terms of sample size and length, but they do not differentiate between measures of controls on capital inflows and outflows or regulations based on foreign-exchange transactions.

A number of authors, including Schindler (2009), Quinn, Martin, and Toyoda (2011), Ostry et al. (2012) and Erten and Ocampo (2017) have subsequently developed measures of regulations aimed at taking account of these differences. We follow this literature and build on Erten and Ocampo (2017) to distinguish between four different types of capital account regulations, capturing some of the varieties of capital controls discussed in section 2.1: (i) capital inflow controls; (ii) capital outflow controls; (iii) financial sector regulations, and (iv) regulations on the domestic use of foreign exchange (FX-related regulations). The first and second are indices constructed by taking simple averages of binary capital control measures across six asset categories: money market instruments, bonds, equities, financial credits, collective instruments, and direct investment. The third is an index constructed by a simple average of binary measures of financial-sector specific capital controls, including the capacity of non-residents to hold domestic accounts and limits on residents' capacity to borrow and hold accounts abroad. Lastly, FX-related regulations is an index constructed by a simple average of restrictions on the domestic use of foreign currencies, including lending locally in such currencies, the purchase of locally issued securities denominated in foreign currencies, differential treatment of deposit accounts in such currencies, and limits on foreign exchange positions. All of these measures range from 0 (no regulations in a given variety of capital controls) to 1 (regulations present in every subcategory of a given variety).

Figure 5 plots the cross-country averages of these capital account regulations

remaining economies. Please refer to Appendix I in Chinn and Ito (2017) for the complete list of countries. 


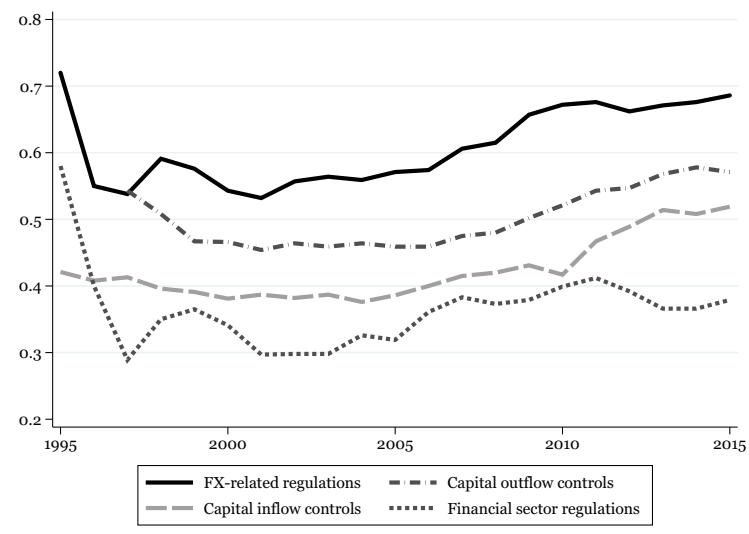

Figure 5: Capital account regulations, $1995-2015$

Source: Erten and Ocampo (2017) based on data from the IMF's Annual Report on Exchange Arrangements and Exchange Restrictions (AREAER) database

across 51 emerging and developing economies from 1995 to 2015 . We observe that the most commonly used measures are FX-related regulations, followed by capital outflow controls, capital inflow controls, and financial sector regulations. Over time, countries reduced FX-related and financial sector regulations in the run-up to the East Asian financial crisis, and began to tighten these regulations after the crisis. This was accompanied by relaxing capital controls on outflows. Moreover, emerging and developing countries generally increased their regulations during and after the 2008-09 Global Financial Crisis, with the exception of financial sector regulations.

\subsection{Channels}

The are several different channels through which capital controls affect the economy and that are identified in empirical work. The direct channel is that capital controls change the cost of international capital or limit the quantities of flows. This is the channel that was analyzed in the theoretical framework of section (1.2). However, there are also several indirect channels through which capital controls affect international capital flows and that are empirically relevant, in particular the signaling channel and the expectations channel of capital controls.

The direct effects of capital controls are documented in a number of studies that focus on firm-level data and find that inflow controls achieve their desired goal of increasing the cost of capital, and that this affects firm-specific outcomes, such as equity returns, stock prices, and investment. For example, Alfaro, Chari, and Kanczuk (2017) use quarterly data from 2006 to 2012 to examine the effects of capital controls on Brazilian firms' stock returns and real investment. Their findings show that the greater cost of capital following capi- 
tal control announcements results in a decline in cumulative abnormal returns and a fall in real investment, and these effects are larger for smaller and more external-finance dependent firms. Similarly, Forbes (2007) finds that Chile's reserve requirements on capital inflows from 1991 to 1998 increased the cost of financing for smaller firms. This evidence supports theoretical insights that predict cross-sectional variation in stock prices and declines in real investment by firm-type (Chari and Henry, 2004 and 2008). This is reminiscent of the disproportionate effects of monetary policy on smaller firms that are subject to tighter financial constraints (see e.g. Gertler and Gilchrist, 1994).

The signalling channel observes that the capital control policy followed by policymakers provides signals to foreign investors about the type of policymaker imposing them. Foreign investors will accordingly respond by adjusting their investment position. Bartolini and Drazen (1997a, b) and Drazen (1997) propose that investors may interpret capital controls as a signal that authorities are reluctant to commit to appropriate fiscal and monetary policies for maintaining stability. They may also interpret capital controls as a signal of a hostile environment towards foreign investment, creating stigma effects that lead to disproportionate capital outflows as foreign investors reassess the desirability of investing in a specific country. Conversely, costly signals such as freely allowing for capital outflows in adverse states of nature may allow policymakers to build a reputation that they follow investor-friendly policies. Jinjarak, Noy, and Zheng (2013) empirically examine the effects of Brazil's capital controls after the Global Financial Crisis and find that the relaxation of capital controls prevented further declines in capital inflows. They argue that the main channel at work was the signal perceived by the market that authorities were more welcoming to foreign investors.

Signaling and the associated stigma and reputation effects may create a bias among policymakers against the use of capital controls, even under conditions when their use might otherwise be appropriate. Signaling effects may substantially affect international capital flows, and may also explain why many central banks perceive capital controls as a policy of last resort. In fact, the traditional stigma associated with the term "capital controls" was one of the key reasons for why the IMF has coined the phrase "capital flow management measures", and why others have referred to them as "capital account regulations" or "capital flow policies". The motivation is that if the word "controls" has been removed, it would be perceived just as any other financial regulation, and the negative connotation would be alleviated.

However, signaling effects depend by their very nature on the interpretation assigned to the signal. In prior decades, capital controls have frequently been associated with autocratic governments that expropriate international investors. By contrast, going forward, if countries impose capital controls as prudential regulation in accordance with state-of-the-art economic theory and as sanctioned by international institutions like the IMF, this will in fact provide a positive signal that policymakers possess state-of-the-art regulatory capabilities, which will increase financial and macroeconomic stability, and may make a country a more desirable destination for foreign capital. For example, the use of capital 
controls by Chile in the late 1990s has been perceived as a signal that authorities have a serious commitment to stabilize foreign exchange and financial markets (Eichengreen and Mussa, 1998).

The expectations channel of capital controls arises because the imposition of capital controls provides international investors with new information about the economic environment rather than about the type or reputation of the policymaker imposing the controls as would be captured by the signaling channel. For example, in many cases, outflow controls have been interpreted as indicating that policymakers are desperate, and that financial markets are on the brink of collapse. Rossi (1999) finds that capital outflow controls are associated with a higher risk of currency and banking crises (although there may be some reverse causality). Forbes et al. (2016) provide evidence that the signaling and expectations channels played an important role in explaining the effects of Brazil's tax on foreign investment in bonds on foreign investors' portfolio allocation. They document expectational spillover effects by interviewing foreign investors and find that Brazil's imposition of capital controls significantly affected investor expectations about future policies in both Brazil and other countries. In response, foreign investors increased their capital allocation to other countries with large exposure to China while they reduced their allocations to countries that were perceived as more likely to also impose capital controls in the future in response to Brazil's move.

\subsection{Effects of Capital Controls on Financial Fragility}

Financial stability is one of the major concerns for why countries may want to consider the use of capital controls, as we observed in the theory section 1.3. We synthesize the empirical literature on capital controls and financial fragility by focusing on (i) studies using traditional annual data sources, (ii) studies using higher frequency data, and (iii) mechanisms through which capital controls may impact financial outcomes. In each section, we highlight the advantages and limitations of each approach, and distinguish between the effects of different types of capital controls on financial fragility.

A major concern in estimating the impact of capital controls on financial outcomes is that changes in capital controls are often introduced in response to changes in foreign capital inflows or fluctuations in the exchange rate. Hence, a credible identification strategy needs to properly account for the endogeneity of capital controls to financial fragility indicators. For example, countries that impose a tax on capital inflows (e.g. Brazil) generally increase the tax after inflows increase and reduce it when inflows decline significantly. If one estimates the impact of such capital controls on capital inflows without addressing the endogeneity problem, the estimates would be downward biased and could even go in the opposite direction, wrongly suggesting that the capital controls caused the surge in inflows. The fundamental issue is that finding a valid instrument to exogenously predict the use of capital controls while satisfying the exclusion restriction is extremely challenging. For this reason, many studies in this literature fail to be well-identified, and one should be cautious that the estimates 
might be severely downward biased.

Studies using traditional annual data sources A large body of empirical work uses annual data sources, many of which are ultimately based on the IMF's AREAER database. These studies typically examine whether the use of capital controls reduces financial fragility by regulating credit growth and lengthening the maturity of foreign debt flows. They can be distinguished into whether they focus on capital controls on inflows or outflows, and whether they differentiate between structural or cyclical capital controls.

One of the consistent findings that emerge from this strand of literature is that capital controls have a robust impact on the composition of capital flows by reducing relatively short-term and increasing long-term flows, without generally having a significant effect on the total volume of capital flows. Reviewing more than 30 empirical studies, Magud, Reinhart, and Rogoff (2018) find that capital inflow controls tend to be more effective relative to outflow controls in altering the composition of capital flows toward longer-term flows and improving monetary policy independence. ${ }^{18}$ However, they document mixed results in terms of the effectiveness of capital controls in reducing the volume of capital flows. Other multi-country studies confirm that capital controls affect the composition of flows, without having a discernible effect on the volume of flows (Reinhart and Smith, 2002; Montiel and Reinhart, 1999).

The restrictiveness of the regulations may be a critical issue in determining whether the volume of flows is affected. In a comparative study of the effects of capital controls on inflows in Chile, Colombia, and Malaysia in the 1990s, Ocampo and Palma (2008) concluded that the more restrictive 1994 Malaysian regulations had a stronger effect than those of Chile or Colombia, and that, among the latter, Colombia's were more effective because they were also stronger, as measured by the tax equivalent of the unremunerated reserve requirements (URRs). Similarly, the strong tax introduced by Malaysia in 1998 is generally considered to have been very effective in reducing outflows (Kaplan and Rodrik, 2002). ${ }^{19}$

In a related vein, Ostry et al. (2011a, 2011b, 2012) test whether capital inflow controls reduce indicators of financial fragility, and find that inflow controls are associated with a lower proportion of FX lending in total domestic bank credit, and with a lower proportion of portfolio debt in total external liabilities. The results also indicate that domestic prudential policies (e.g. loan-to-value ratios and sector-specific credit policies) and FX-related regulations (e.g. limits on banks' open FX positions or exposure to currency mismatch) complement capital controls on inflows in reducing domestic credit booms and overall financial

\footnotetext{
${ }^{18}$ The empirical studies included in their review indicate that capital outflow controls in Malaysia reduced capital outflows and tended to give room for more independent monetary policy; however, the case of Malaysia seems to be an outlier compared to other countries' experience with outflow controls where the success has been more limited (Magud, Reinhart, and Rogoff, 2018).

${ }^{19}$ Examining the effectiveness of capital controls in the 1990s, Ariyoshi et al. (2000) concluded that regulations on outflows were more effective than those on inflows in this period.
} 
fragility (Ostry et al. 2012).

Klein (2012) distinguishes between structural capital controls (i.e. longstanding controls, often more quantity-based) and cyclical capital controls (i.e. episodic controls, often more price-based). He finds that countries that use structural capital controls have less growth in financial fragility indicators than countries that impose cyclical capital controls. However, one difficulty in interpreting this result is the dualism between fixed quantity controls and cyclical price-based controls that we pointed out in section 2.1. Moreover, Klein (2012) shows that controlling for the fact that countries with structural capital controls have much lower GDP per capita, there is no evidence of a significant impact of either structural or cyclical controls on financial fragility.

Empirical challenges A general caveat of these studies is that the timing of capital controls implemented at a monthly frequency may not be properly captured by annual indices. The annual frequency data from the IMF's AREAER database records in a binary fashion whether countries use any measure of capital flow restrictions on specific asset categories, such as equities, bonds, collective instruments, etc. The annual indicators take on values of zero or one, depending on whether a restriction on international transactions for an asset category is present or not, and hence tend to show little variation over time. If, for example, a country increases the tax rate on cross-border equity inflows from one year to the next, it still continues to be assigned a value of one, masking any cyclical adjustments. As we discuss more below, studies using higher frequency data were able to capture these short-term changes better.

Another reason to be cautious about estimates from studies using crosscountry annual data is that it is difficult to find valid instruments to control for endogeneity of capital controls. For instance, while Klein (2012) uses only lagged values of capital controls to partially address this issue, Ostry et al. (2012) use lagged values together with an instrumental variables strategy. In particular, they use two instruments-bilateral investment treaties with the U.S. and the E.U. membership agreements - to predict whether countries use capital controls. Since these international agreements prohibit the use of capital controls, they generate some variation that is plausibly exogenous to outcome variables of interest although the predictive power is generally low, resulting in weak instruments.

A related question in the empirical literature on financial fragility is whether capital controls have been adjusted at a business-cycle frequency by the policy authorities. Using annual indices from the IMF's AREAER database, Fernández, Rebucci, and Uribe (2015) provide evidence that capital controls are acyclical - that is, the use of capital controls is not associated with boom-bust episodes in output, the current account, or the real exchange rate. Similarly, Eichengreen and Rose (2014) and Gupta and Masetti (2018) show empirically that controls on international capital flows have been highly stable over time and argued that this fact poses a challenge to proposals of using capital controls as instruments of macroprudential management given the little experience in 
using them as counter-cyclical instruments through the business cycle.

There may be a number of reasons for why these studies have failed to identify a systemic policy response to capital flows. First, both the economic literature and international policy community have only recently proposed that it may be desirable to use capital controls as cyclical policy tools. This may explain why little cyclical use is visible in data going back decades. The second reason is sample composition. Some of the studies combine middle-income emerging market economies together with high-income and low-income countries over long periods of time, resulting in a heterogeneous sample. Given that the challenges posed by capital flows vary by type of economy, systematic responses are difficult to document in such large and heterogeneous samples. The third reason is that these studies use slow-moving annual indices that capture whether restrictions are present or not, instead of the cyclical variations of restrictions over the business cycle. Because many countries only adjust the restrictiveness of capital controls (for example, by reducing or increasing taxes on inflows), the indices focusing on the presence/absence of restrictions will not capture such intensity changes. Finally, there is also selection bias. The countries that adjust their capital controls and countries that have high levels of restrictions have different characteristics than other countries. For example, countries such as Brazil, Chile, South Korea, Indonesia, and Thailand adjust their restrictions on capital flows more frequently, and several emerging market economies in Asia (notably, China and India) have significantly tighter capital controls than other regions. The selection problem poses a significant empirical challenge for studies that aim to generate causal estimates of the effects of capital controls. Given the little within-country variation for annual indicators, most studies cannot use country fixed effects to isolate the impact of time-invariant country characteristics on outcome variables. While some use region fixed effects, given the large and systematic differences across countries within regions, this may not be sufficient to address the selection issue.

Studies using higher frequency data In response to the empirical challenges of using annual data, a number of studies have used higher frequency data (weekly, monthly, or quarterly) that better captures time variation, and adopted alternative empirical strategies to address the selection problem. Using quarterly data for a more coherent sample of 50 emerging market economies over 2005-2013, Ghosh, Ostry, and Qureshi (2017a) analyze the set of policy instruments that countries employ to respond to capital inflow surges, ranging from monetary and fiscal policy to exchange rate interventions and capital controls. They find that central banks increase policy interest rates to reduce inflation and overheating, and controlling for these, they tend to reduce interest rates in the face of currency appreciation pressures. The majority of central banks also intervene heavily in the foreign exchange market, purchasing close to 30-40 percent of capital inflows. On the other hand, fiscal policy is either acyclical or procyclical, without evidence of a tightening during inflow surges. Finally, macroprudential tools (such as reserve requirements and loan-to-value 
and debt-to-income ratios), controls on bond inflows, and currency-based prudential measures are used in response to large portfolio and other investment flows rather than in response to FDI. This evidence implies that the overall policy response in emerging markets has been far from being acyclical: countries use a number of tools and respond more during inflow surges than in normal times.

Using weekly frequency data for 60 countries from 2009 through 2011 and employing a propensity-score matching method to address selection, Forbes, Fratzscher, and Straub (2015) find that capital flow measures have a robust effect on reducing financial vulnerability. In particular, they find that an increase in these measures lead to a reduction in bank leverage, inflation expectations, bank credit growth, and exposure to portfolio liabilities. However, they find no evidence of a significant impact on net capital inflows or real exchange rates.

This evidence is consistent with findings from the earlier individual-country studies using high frequency data. Focusing on the use of unremunerated reserve requirements (URRs) in Chile in the 1990s, several studies have consistently shown that the URRs have had a significant impact on the composition of capital inflows, shifting the composition toward longer maturity (De Gregorio, Edwards, and Valdes, 2000; Edwards, 1999; Gallego, Hernandez, and Schmidt-Hebbel, 2002; Laban, Larrain, and Chumacero, 1997; Laban and Larrain, 1998; Laurens and Cardoso,1998; Le Fort and Budnevich, 1998; Reinhart and Smith, 1998; and Valdes-Prieto and Soto, 1995). Similar effects have also been documented for the experience of Colombia with URRs in the 1990s (Le Fort and Budnevich, 1998; Ocampo and Tovar, 2003; Baba and Kokenyne, 2011), the use of capital inflow controls in the Czech Republic in the 1990s and in Malaysia in 1989 (Reinhart and Smith 1998), and again the use of capital inflow controls in Malaysia in 1994 (Ariyoshi et al. 2000).

In contrast, using quarterly information from local press releases and news bulletins for 19 emerging market economies from 2002Q1-2013Q2 and adopting a fixed-effects model, Ahmed and Zlate (2014) find that capital controls have a significant negative impact on both total and portfolio net inflows for the period 2009Q3-2013Q2, during which a large number of countries tightened their controls on portfolio inflows. Using the same data on capital controls, Akinci and Olmstead-Rumsey (2018) illustrate that domestic prudential policies are usually adjusted in tandem with bank reserve requirements, capital flow restrictions, and monetary policy. Their dynamic panel analysis of 57 countries from 2000Q1-2013Q4 shows that macroprudential tightening is associated with lower bank credit growth, housing credit growth, and house price appreciation.

Using monthly data from January 2000 to August 2008 for Brazil, Colombia, Korea, and Thailand, Baba and Kokenyne (2011) find that capital controls are associated with a decline in capital inflows and a lengthening of maturities; however, the estimated effects are temporary. In a similar vein, Jordà, Schularick, and Taylor (2011) use long-run historical data from 1870 to 2008 for 14 developed countries to examine whether external imbalances increase the risk of financial crises. Their findings show that credit growth is the single best predictor of financial instability, and even though external imbalances have 
played an additional role, this was more the case in the pre-WWII era of low financialization than today.

To summarize, empirical studies using annual data to capture restrictions on international capital flows face more significant constraints in measuring the intensity of capital flows and distinguishing them from time-invariant country characteristics. More recent studies that use higher-frequency data sources and alternative empirical methodologies to address selection generally reach more consistent conclusions. In particular, their findings show that a tightening in capital controls reduces financial fragility indicators such as bank leverage, bank credit, and exposure to portfolio liabilities; and their increased intensity in the post-crisis period has led to a decline in net capital inflows, particularly net portfolio flows. In cases where domestic prudential regulations were used as complements to capital flow restrictions, there is also evidence that this has led to a decline in private credit growth and appreciation of housing prices, improving overall financial stability. The mechanisms through which capital controls affect capital flows range from the direct effects of increasing the cost of borrowing from abroad to the signal sent to international financial markets about future government policies. The degree to which these channels may be at work depends on the implied cost of capital control policies and the different perceptions of the signals by the markets.

\subsection{Effects of Capital Controls on Macroeconomic Outco- mes}

The empirical literature has analyzed how a wide range of macroeconomic outcomes is affected by capital controls, going beyond the theoretical literature that we surveyed in section 1.4 above in a number of directions. In the following, we synthesize the findings of this literature on (i) long-term growth effects, (ii) short-term growth and consumption volatility effects, (iii) real exchange rate effects, and (iv) effects on monetary policy independence. We provide a review of the findings for each set of outcomes, and explain differences in empirical methodologies employed.

\section{Long-term growth}

Empirical studies that focus on the relationship between long-term economic growth and restrictions on capital flows (or financial openness more broadly) generally begin with testing the hypothesis that capital account liberalization would lead to flows of capital from capital-abundant economies to capital-scarce economies due to higher returns to capital in the latter ones. However, as famously shown by Lucas (1990), the actual volumes of capital flows in fact follow the opposite prediction, as capital-scarce countries finance the balance of payments deficits of capital-abundant countries. Nevertheless, the key theoretical prediction remained that foreign capital inflows provide necessary funding for saving-constrained economies, and by reducing the cost of capital, allow for 
higher levels of investment and long-term growth. ${ }^{20}$

In one of the most influential and detailed surveys of this literature, Kose et al. (2009) conclude that the cross-country evidence on the effects of capital account liberalization on long-term economic growth is inconclusive and lacks robustness. Their own analysis also shows no evidence of a positive association between growth and financial openness. Instead, they argue that the benefits of financial openness do not come from enhanced access to financing for domestic investment, but rather result from indirect (or collateral) benefits such as improving financial sector development and imposing discipline on public and private borrowers. In another paper, Kose, Prasad, and Taylor (2011) have shown that these collateral benefits are only realized after some thresholds in institutional quality are reached. Rodrik and Subramanian (2009) also find no evidence of a robust relationship between long-term growth and financial openness. In contrast, in a seminal review of the empirical literature, Henry (2007) has argued that most empirical studies fail to find a positive effect of capital account liberalization on growth because they search for permanent effects on the growth rate whereas the Solow growth model predicts that a permanent decrease in the cost of capital and a resulting increase in the investment-to-GDP ratio would shift the level of output, i.e. it would only have a temporary effect on the growth rate. He also demonstrated the weaknesses in the measurement of capital control indices, which make it harder to empirically investigate the theoretical predictions. Bekaert, Harvey, and Lundblad (2005) find that equity market liberalizations specifically increase economic growth.

However, as Rodrik and Subramanian (2009) argued, the Solow growth model is not the only theoretical framework that motivates growth regressions, and endogenous growth models predict policies to have long-run effects, motivating a large literature on growth effects of trade policy, fiscal policy, and other structural policies. Regarding the collateral benefits argument, Rodrik and Subramanian (2009) argue that this is not self-evident since financial openness may also weaken discipline of domestic actors and undermine institutional development. One example of the latter mechanism could be that improved access to foreign finance may enable profligate governments to function with soft budget constraints for more extended periods than otherwise possible. Moreover, given that other potentially long-term factors that affect growth (such as education and undervalued exchange rates) have displayed strong correlations with long-term growth, it is also problematic to claim that the effects of financial openness are inherently more difficult to detect in the long-run. Instead, Rodrik and Subramanian (2009) argue that most developing countries are not saving-constrained, but rather investment-constrained, and foreign capital inflows during booms appreciate the real exchange rate leading to allocation of resources into lower-productivity non-tradables, and hence reducing overall growth potential. Moreover, Prasad, Rajan, and Subramanian (2007) and Gourinchas and Jeanne (2013) find that fast-growing countries rely less on foreign

\footnotetext{
${ }^{20}$ Gourinchas and Jeanne (2006) evaluate this prediction and show that the resulting welfare gains are actually quite limited even in a purely neoclassical economy with perfect markets.
} 
capital, and that foreign capital generally flows into countries that experience lower productivity growth. Overall, empirical studies in this strand of literature frequently suffer from an endogeneity problem: there can be reverse causality from economic growth to financial openness, and omitted variable bias such that other factors may have an impact on both of these outcomes, both of which make it very difficult to reach a conclusive result.

\section{Output and consumption volatility}

A related body of empirical studies focuses on whether there is a robust relationship between financial integration and output/consumption volatility. Theoretically, improved access to foreign finance has an ambiguous effect on output volatility. On the one hand, it could enable countries to diversify their output, which could result in less sector-specific shocks; on the other hand, it could lead to greater specialization and magnify the effects of sector-specific shocks. Moreover, an increase in external indebtedness can also lead to higher exposure to world interest rate shocks, and thus, to greater volatility in output. In contrast, most theoretical models predict that financial openness would reduce consumption volatility by allowing for consumption smoothing over the business cycle. However, empirical studies find no supporting evidence for this prediction. Kose and Terrones (2005) find that consumption volatility increased relative to output volatility in emerging economies during the period of financial integration. As noted in Kose et al. (2009), this result exactly runs counter to the theoretical benefit of financial openness that it would allow countries to share income risk and smooth consumption. After the 2008-09 Global Financial Crisis, the empirical literature began to shift towards analyzing more directly whether capital inflows may reduce short-term output fluctuations by using more disaggregated measures of capital inflow controls, and testing their effectiveness over the boom and bust phases separately. Several studies have documented that the countries that increased the restrictiveness of capital inflow controls prior to the Global Financial Crisis exhibited more resilience during the crisis, and the countries that used capital controls prior to the post-crisis period experienced less overheating after the crisis (Ostry et al., 2011a, 2011b, 2012; Erten and Ocampo, 2017). These findings suggest that the counter-cyclical use of capital controls help reduce boom-bust cycles in real output growth, which tend to be exacerbated by the volatility of capital flows.

\section{Real exchange rate effects}

Another strand of the empirical literature focuses on whether capital controls reduce real exchange rate appreciation, or result in undervalued real exchange rates. Rodrik (2008) finds that countries with higher capital account openness have less undervalued real exchange rates, or that they suffer from overvaluation pressures. In their review of the literature, Magud, Reinhart, and Rogoff (2018) find that capital inflow controls generally reduce real exchange rate appreciation. In contrast, Klein (2012) finds no evidence of a significant effect of capital 
controls on real exchange rate changes. As in the case of other macroeconomic outcomes, the key problem of endogeneity remains as one examines the relationship between capital controls and real exchange rate fluctuations. There may be reverse causality as countries with greater appreciation may attract more capital inflows, which may trigger the use of more restrictive capital controls. There may be also omitted variables that simultaneously have an impact on both the use of capital controls and the fluctuations in the real exchange rate. In order to address the endogeneity concerns, following Ostry et al. (2012), Erten and Ocampo (2017) use binary variables on whether countries have bilateral investment treaties with the U.S. or whether they signed the E.U. membership agreement, both of which prohibit the use of capital controls, as instruments for whether countries use various capital control measures. The instrumentalvariables regression results indicate that capital control measures as well as foreign-exchange related regulations result in a reduction in real exchange rate appreciation.

Furthermore, most papers look at the effects of regulations on capital inflows and exchange rates as separate effects, but they are in fact two manifestations of the same effect. Erten and Ocampo (2017) took this into account by creating an overall index of the 'foreign exchange pressure' generated by capital flows, which can be reflected either in reserve accumulation or exchange rates -with the mix depending on other macroeconomic policies. Using this methodology, regulations are found to reduce foreign exchange pressures. This in effect is true of emerging and developing countries but not of developed countries.

In a similar vein, Montecino (2018) examines the adjustment dynamics of the real exchange rate under different intensity of restrictions on capital flows, and shows that capital controls increase the persistence of real exchange rate misalignments. In particular, it finds that the real exchange rate converges to its long-run level at significantly lower rates in countries with capital controls. The evidence also shows that this persistence is stronger when the exchange rate is undervalued, and is independent of the exchange rate regime and other confounding factors.

\section{Monetary policy independence}

Finally, a related body of empirical work assesses whether capital controls make monetary policy more independent. The trilemma of open economies implies that it is not possible to have a fixed exchange rate, open capital markets, and monetary policy independence. If a country is open to capital flows, it faces a difficult tradeoff between keeping exchange rate stable and having an independent monetary policy. For example, during booms, monetary policy authorities can raise interest rates to reduce excessive overheating, but only at the cost of an exchange rate appreciation, which may increase the trade deficit and lead to Dutch disease. The use of capital controls on inflows allows authorities to raise interest rates without strong effects on the exchange rate. Hence, regulating capital flows in a counter-cyclical fashion provides a wedge for the effects of capital flows on interest and exchange rates, and thereby, reduces 
the tradeoff between monetary policy independence and exchange rate stability.

The evidence on the monetary policy effects indicates that in most countries capital controls have been effective in improving monetary policy autonomy. In particular, several studies document that capital controls allowed for a more independent monetary policy in Chile in the 1990s (Ariyoshi et al., 2000; Chamon and Garcia, 2016; De Gregorio, Edwards, and Valdes, 2000; Edwards, 1999; Gallego, Hernandez, and Schmidt-Hebbel, 2002; and Le Fort and Budnevich, 1998) and again in the 2000s (Baba and Kokenyne, 2011), in Colombia in the 1990s (Le Fort and Budnevich, 1998; Ariyoshi et al., 2000; Villar and Rincón, 2003) and again in the 2000s (Baba and Kokenyne, 2011), in Malaysia in the 1990s (Ariyoshi et al., 2000; Edison and Reinhart, 2001; Kaplan and Rodrik, 2002; Tamirisia, 2004), and in Thailand in the 1990s (Ariyoshi et al., 2000) and again in the 2000s (Baba and Kokenyne, 2011). Magud, Reinhart, and Rogoff (2018) also note that capital controls have in general been found to increase monetary policy independence, with particularly strong effects in Chile and Malaysia.

\subsection{International Spillover Effects of Capital Controls}

An important question concerns whether capital controls implemented in one country can result in movement of capital flows into or out of other countries. Korinek (2016) shows that international spillover effects are a necessary consequence of capital account policies, and that they do create a case for international policy coordination if countries either engage in strategic capital account manipulation, lack policy instruments to deal with the spillovers, or experience the consequences of imperfections in international capital markets.

Although there are not many empirical studies that focus on international spillovers from capital controls, some papers do find significant spillover effects. Based on a sample of Latin American countries, Lambert, Ramos-Tallada, and Rebillard (2011) use high frequency data on bond and equity flows to analyze the spillover effects of one country's use of capital controls on neighboring countries. Their findings show that an increase in Brazil's tax on portfolio bond inflows in the post-crisis period has led to a rise in portfolio inflows invested in other Latin American countries. Although they find that the effects are temporary and followed by reversals of flows, the initial impact has been documented to be fairly large. In particular, they find that the increase in Brazil's capital inflow tax accounts for the entire rise in bond inflows to Mexico during September and October of 2010.

Forbes et al. (2016) also identify spillover effects of Brazil's capital inflow taxes from 2006 to 2013. As observed in section 2.4, they show that many of the effects on international investors were likely driven by changes in their expectations about future policies rather than by the direct cost of Brazil's inflow taxes. Foreign investors reduced their allocations to countries that they expected to be more likely to also impose capital controls in the future. Giordani et al. (2017) provide evidence that capital controls deflect capital flows to other countries with similar economic characteristics.

Using a novel, high-frequency data on capital controls for 16 emerging market 
economies from 2001 to 2012, Pasricha et al. (2018) find that tightening capital inflow restrictions generated significant spillovers, particularly in the post-2008 period of high global liquidity. They also document that domestic policy makers respond to changes in foreign capital controls in countries that are affected by these spillovers. In particular, they show that countries respond to capital controls in the BRICS by changing their own capital controls.

\section{The Policy Debate}

\subsection{A Brief History of the Policy Debate}

The intellectual fathers of the Bretton Woods Agreement, John Maynard Keynes and Harry Dexter White, both shared the view that free capital movements were major sources of financial instability that had generated substantial problems in the 1920s and had led to the collapse of the world economy in the 1930s. This was reflected, above all, in their view that international capital movements should not be allowed to disrupt the policy space for countries to use monetary policy in pursuit of their domestic priorities, particularly full employment, and the possibility of adjusting exchange rates but within a framework of stable rates to facilitate the reconstruction of international trade in the post-war years (see e.g. Ocampo, 2017, ch. 4).

As part of the commitment to rebuild international trade, the Bretton Woods Agreement obliged countries to eliminate regulations affecting trade and, more broadly, current account transactions - although in a gradual way, given the major payments imbalances that many of them faced. However, it also included the provision that "Members may exercise such controls as are necessary to regulate international capital movements, but no member may exercise these controls in a manner which will restrict payments for current transactions" (Article VI-3 of the Agreement). It also set forth the principle that IMF funds could be used to finance balance of payments deficits associated with current account deficits, but not those originating in the capital account, which were supposed to be managed by capital controls. Moreover, the Agreement suggested cooperation among countries to make capital controls more effective. Whereas the freedom to regulate capital flows has been extensively used by IMF members, these provisions on cooperation have been little used in practice.

The OECD Code of Liberalization of Capital Movements was adopted when the organization was created in 1961, but allowed countries to lodge "reservation" to liberalization of specific transactions when they joined the OECD, and they were also allowed by Article 7 of the Code to apply temporary (12-18 months) "derogations" of the commitments when facing economic and financial disturbances that justified reversing the liberalization process, or when facing severe balance of payments problems. Although the Code was expanded in later decades, these provisions in practice allowed for a very gradual liberalization of the capital account for the original (developed country) members as well as by the new entrants to the OECD from Southern Europe (Griffith-Jones, Gottschalk, 
and Ciara, 2003).

The reconstruction of private global finance after World War II began to take shape in the late 1950s in the Eurodollar market, which derived its name from the fact that it was the first market to trade US dollars off-shore in Europe, particularly in London. However, it came with the balance of payments pressures generated by cross-border capital flows - either positive or negative, depending on the individual country. These pressures led to the strengthening of capital account regulations, which focused on either reducing inflows (Germany was the pioneer in this regard) or mitigating outflows (including France and the UK in Western Europe, but also the US in the early 1960s). This also demanded new forms of balance of payments financing, in particular swap arrangements among the central banks of major developed countries, sometimes intermediated by the Bank for International Settlements, and larger IMF packages - in the latter case, violating in a sense the principle that such financing should not be available to finance capital outflows.

What this implied is that, although the development of the London-centred offshore market since the late 1950s did lead to growing cross-border capital flows, and the OECD Code of Liberalization was in place since 1961, the industrial countries reacted by using the various mechanisms provided by the Code and allowed by the IMF to moderate capital account movements. The broadbased shift toward liberalizing capital flows only started with the US in 1974 and, as we have seen, then spread to the rest of the developed world in the second half of the 1970s and through the 1980s and, as we saw in Section 2.2, was essentially completed by the early 1990s. The process was aided by the adoption of stronger OECD principles on capital account liberalization in the late 1980s, which forced most recent members to remove capital account regulations more quickly, and by the full liberalization of capital flows in the European Union in 1990.

As we also showed in Section 2.2, capital account liberalization was slower and less widespread in the emerging and developing world. In the 1980s, there were several prominent critics within the Bretton Woods institutions to this trend. In particular, Sebastian Edwards at the World Bank and Jacob Frenkel at the IMF argued that capital account liberalization should be well sequenced, and that capital controls were needed through the transition to guarantee macroeconomic stability (Edwards, 1989; Frenkel, 1983). Over the course of the 1990s, many emerging and developing countries nonetheless joined the trend under the influence of the neoliberal "Washington Consensus" of the 1990s. ${ }^{21}$

In the late 1990s the US Treasury explicitly promoted capital account liberalization in developing countries (Abdelal, 2007). As many developing countries experienced slow growth and were looking for new policies to stimulate their economies, opening up to foreign capital flows seemed like a new way of achieving

\footnotetext{
${ }^{21}$ The term "Washington Consensus" was first used by John Williamson in 1989 to describe a set of policy reforms that were widely viewed as desirable within the IMF, the World Bank, and the US Treasury at the time. Originally, these reforms only included the liberalization of inward FDI. Later, the term came to be understood more broadly to encompass a wider neoliberal reform agenda that included broad capital account liberalization.
} 
this goal (see, Reinhart and Rogoff, 2009, for a discussion of these processes, based on similar episodes in the Southern Cone of Latin America in the 1970s). The peak of this process was a proposal presented by the IMF Managing Director, no doubt supported by the US, to the Annual Meetings of the IMF in Hong Kong in 1997 to include capital account convertibility (liberalization) alongside current account convertibility, as an obligation of its members in the IMF Articles of Agreement. However, this proposal was not accepted, no doubt under the difficulties generated by the East Asian Financial Crisis, which was already under way at the time.

\subsection{Recent Policy Debates and the IMF Institutional View of 2012}

The East Asian Crisis was a turning point in the debate on capital account liberalization and management. The literature on the risks of capital account liberalization and the effects of capital controls proliferated, as we have seen throughout this paper. Beginning in early 2000s, a research team at the IMF led by the Chief Economist Kenneth Rogoff, provided a review of the literature and argued that the evidence for the benefits of greater capital account liberalization on economic growth and stability was weak at best (Kose et al., 2003, 2009). Moreover, the first major research by the IMF on capital controls, issued while the East Asian crisis was still blowing, indicated that controls on inflows and outflows were being actively used by emerging and developing countries, and they were in many cases effective in reducing the risks associated with liberalization (Ariyoshi et al, 2000).

However, the most interesting policy debates on the issue have taken place after the Global Financial Crisis. The most important multilateral effort to rethink the role of these regulations was undertaken by the IMF in 2011 and 2012, leading to what came to be called the IMF "Institutional View" on capital account liberalization and management (IMF, 2012). ${ }^{22}$ This exercise was backed by significant research by IMF staff, which has been extensively quoted in this paper (see, in particular, the summary of this research in Ghosh, Ostry, and Qureshi, 2017b). The IMF recognized that, although capital flows bring benefits, they carry risks and, therefore, under certain circumstances, they should be regulated to moderate both surges and sudden stops in external financing. In broader terms, it concluded that "there is no presumption that full liberalization is an appropriate goal for all countries at all times" (IMF, 2012, par. 18) and, particularly, that this goal should only be adopted when nations reach a certain threshold of financial and institutional development.

The major recommendation was that nations should use "capital flow mana-

The G-20 also adopted a set of "coherent conclusions for the management of capital flows" during its 2011 Summit (G-20, 2011). The Financial Stability Board, by contrast, which was given the responsibility to strengthen financial regulation and supervision to reduce systemic risk in financial markets, left out policies to reduce the risks of cross-border capital flows.
} 
gement measures" (CFMs), as the IMF termed capital controls in this report, alongside other macroeconomic policies: counter-cyclical monetary and fiscal policies, active foreign exchange reserve management, and macroprudential domestic financial regulations. However, a major limitation of the institutional view is that it tends to view capital account regulations as interventions of last resort rather than as an integral part of counter-cyclical macroeconomic policy (Gallagher and Ocampo, 2013). In this alternative view, macroprudential regulations on the capital account should be seen as permanent regulations that are strengthened or weakened in a counter-cyclical way, and dynamically modified to respond to developments in global and local capital markets.

The institutional view was also a restatement of the principle that there is no obligation to adopt capital account convertibility under the IMF Articles of Agreement, an issue that was settled after the 1997 debates. In the words of the major grouping of developing countries in the Bretton Woods institution, the G-24, when this debate was ongoing: "Policy makers of countries facing large and volatile capital flows must have the flexibility and discretion to adopt policies that they consider appropriate and effective to mitigate risks" (G-24, 2011, par. 8).

An important recognition of the institutional view was that the freedom that countries have to regulate capital flows may be at odds with other international commitments. It stated that: "even where the proposed institutional view recognizes the use of inflow or outflow CFMs as an appropriate policy response, these measures could still violate a member's obligations under other international agreements if those agreements do not have temporary safeguard provisions compatible with the Fund's approach" (IMF, 2012, par. 42). This is true of commitments on financial service liberalization made within the WTO and OECD but, particularly, of regional and bilateral trade and investment treaties - notably those in which the US is involved - that require that all forms of capital must flow "freely and without delay" among trade and investment partners. The IMF thus suggested that its institutional view could help guide future trade treaties and that the IMF could serve as a forum for such discussions.

The institutional view also indicated that source countries should pay attention to the potentially negative spillover effects of their macroeconomic policies. This is line with the view in the academic literature on the fact that financial regulations generate spillovers that may call for policy coordination (Korinek, 2016). However, these recommendations on international cooperation have had little effect in practice. It remains to be seen whether the ongoing discussions in the IMF on this issue will lead to a more nuanced approach to controls, or perhaps to the adoption of an international regime determining which regulations are appropriate and which are not, as well as an IMF code of good practice for capital account policies, as Jeanne, Subramanian, and Williamson (2012) have proposed.

For its part, the OECD Code of Liberalisation of Capital Movements, which was revised in 2019 (OECD, 2019), agreed with the need to keep the space for macroprudential policies to manage the financial stability concerns associated with capital account volatility. It thus kept the possibility for countries to 
propose reservations and temporary derogations, so long as they maintain the principles of transparency, accountability and proportionality. Actually, the new Code underscored the role of special policies to managing capital inflow surges, including temporary derogations of the Code, but stated the preference for possible restrictions on inflows rather than outflows.

\section{Conclusion}

The recent theoretical and empirical literature on capital controls provides a useful framework to guide academics and policymakers on how to regulate international capital flows. We summarize the theoretical rationale for the use of capital controls to induce private investors to internalize their contribution to financial instability and aggregate demand. We synthesize these insights with recent findings that capital controls do indeed lead to improvements in financial stability in the empirical literature, particularly when they are used countercyclically. By combining these two elements, our article provides an integrated account of the recently developed new literature on capital controls.

\section{References}

Abdelal, R. 2007. Capital Rules: The Construction of Global Finance. Cambridge, MA: Harvard University Press.

Admati, A., and M. Hellwig. 2013. The Bankers' New Clothes: What's Wrong with Banking and What to Do about It. Princeton and Oxford: Princeton University Press.

Aghion, P., P. Bacchetta, and A. Banerjee. 2000. "A Simple Model of Monetary Policy and Currency Crises." European Economic Review 44 (4-6): 728-38.

Aghion, P., P. Bacchetta, and A. Banerjee. 2001 "Currency Crises and Monetary Policy in an Economy with Credit Constraints." European Economic Review 45 (7): 1121-50.

Ahmed, S. and A. Zlate. 2014. "Capital flows to emerging market economies: a brave new world?" Journal of International Money and Finance, 48, 221248.

Akinci, O. and J. Olmstead-Rumsey. 2018. "How effective are macroprudential policies? An empirical investigation." Journal of Financial Intermediation, $33,33-57$.

Alfaro, L., A. Chari, and F. Kanczuk. 2017. "The real effects of capital controls: Firm-level evidence from a policy experiment." Journal of International Economics 108: 191-210.

Ariyoshi, A., K. Habermeier, B. Laurens, I. Ötker-Robe, J.I. Canales-Kriljenko, and A. Kirilenko. 2000. "Capital Controls: Country Experiences with Their 
Use and Liberalization." Occasional Paper, No. 190, Washington, DC: International Monetary Fund.

Baba, C. and A. Kokenyne. 2011. "Effectiveness of Capital Controls in Selected Emerging Markets in the 2000's." IMF Working Paper No. 11/281, December.

Bartolini, L. and Drazen, A. 1997a. "Capital account liberalization as a signal." American Economic Review 87(1): 138-154.

Bartolini, L. and Drazen, A. 1997b. "When Liberal Policies Reflect Shocks, What Do We Learn?" Journal of International Economics 42 (3-4): 249-73.

Bekaert, G., C.R. Harvey, and C. Lundblad. 2005. "Does Financial Liberalization Spur Growth?" Journal of Financial Economics 77(1): 3-55.

Benigno, G., H. Chen, C. Otrok, A. Rebucci, and E.R. Young. 2013. "Financial Crises and Macro-Prudential Policies." Journal of International Economics 89 (2): 453-470.

Benigno, G., H. Chen, C. Otrok, A. Rebucci, and E.R. Young. 2016. "Capital Controls or Exchange Rate Policies? A Pecuniary Externality Perspective." Journal of Monetary Economics 84: 147-165.

Benigno, G., H. Chen, C. Otrok, A. Rebucci, and E.R. Young. 2019. "Optimal Policy for Macro-Financial Stability." Manuscript, LSE.

Bernanke, B. and M. Gertler. 1985. "Inside the Black Box: The Credit Channel of Monetary Policy Transmission." Journal of Economic Perspectives 9 (4): $27-48$.

Bernanke, B. and M. Gertler. 1989. "Agency Costs, Net Worth, and Business Fluctuations." American Economic Review 79 (1): 14-31.

Bernanke, B., M. Gertler, and S. Gilchrist. 1999. "The Financial Accelerator in a Quantitative Business Cycle Framework." Handbook of Macroeconomics, Vol. 1C, edited by John B. Taylor and Michael Woodford, 1341-93. Amsterdam: Elsevier B.V.

Bhagwati, J. 1998. "The Capital Myth: The Difference between Trade in Widgets and Trade in Dollars." Foreign Affairs 77: 7-12.

Bianchi, J. 2011. "Overborrowing and Systemic Externalities in the Business Cycle." American Economic Review 101 (7): 3400-3426.

Bianchi, J., E. Boz, and E.G. Mendoza. 2012. "Macroprudential Policy in a Fisherian Model of Financial Innovation." IMF Economic Review 60(2):223269.

Boz, E. 2009. "Can Miracles Lead to Crises? The Role of Optimism in Emerging Markets Crises." Journal of Money, Credit and Banking 41(6):1189-1215.

Caballero, R.J. and A. Krishnamurthy. 2003. "Excessive Dollar Debt: Financial Development and Underinsurance." Journal of Finance 58 (2): 867-893. 
Caballero, R.J. and G. Lorenzoni. 2014. "Persistent appreciations and overshooting: A normative analysis." IMF Economic Review 62: 1-47.

Calvo, G. 1998. "The Simple Economics of Sudden Stops." Journal of Applied Economics 1: 35-54.

Céspedes, L.F., R. Chang, and A. Velasco. 2004. "Balance Sheets and Exchange Rate Policy." American Economic Review 94 (4): 1183-1193.

Chamon, M. and M. Garcia. 2016. "Capital Controls in Brazil: Effective?" Journal of International Money and Finance 61:163-187.

Chang, R. and A. Velasco. 2000a. "Financial Fragility and the Exchange Rate Regime." Journal of Economic Theory 92 (1): 1-34.

Chang, R. and A. Velasco. 2000b. "Liquidity Crises in Emerging Markets: Theory and Policy." NBER Macroeconomics Annual 14: 11-78.

Chang, R. and A. Velasco. 2001. "A Model of Financial Crises in Emerging Markets." The Quarterly Journal of Economics 116 (2): 489-517.

Chari, A. and P.B. Henry. 2004. "Risk sharing and asset prices: evidence from a natural experiment." The Journal of Finance 59 (3): 1295-1324.

Chari, A. and P.B. Henry. 2008. "Firm-specific information and the efficiency of investment." Journal of Financial Economics, 87(3): 636-655.

Cheng, I.H., S. Raina, and W. Xiong. 2014. "Wall Street and the Housing Bubble." American Economic Review 2014, 104(9): 2797-2829.

Chinn, M.D. and H. Ito. 2006. "What Matters for Financial Development? Capital Controls, Institutions, and Interactions." Journal of Development Economics 81 (1): 163-192.

Chinn, M.D. and H. Ito. 2008. "A New Measure of Financial Openness." Journal of Comparative Policy Analysis, 10 (3): 309-22.

Chinn, M.D. and H. Ito. 2017. "Notes on The Chinn-Ito Financial Openness Index, 2015 Update." http://web.pdx.edu/ ito/Readme_kaopen2016.pdf.

Dávila, E. and A. Korinek. 2018. "Pecuniary Externalities in Economies with Financial Frictions." Review of Economic Studies 85 (1): 352-395.

De Gregorio, J., S. Edwards, and R. Valdes. 2000. "Controls on Capital Inflows: Do They Work?" Journal of Development Economics 3 (1): 59-83.

Dornbusch, R. 1998. "Capital Controls: An Idea Whose Time Is Gone." Massachusetts Institute of Technology.

Drazen, A. 1997. "Policy Signaling in the Open Economy: A Re-Examination." NBER Working Paper 5892.

Edison, H. and C.M. Reinhart. 2001. "Stopping Hot Money: On the Use of Capital Controls during Financial Crises." Journal of Development Economics 66 (2): 533-553. 
Edwards, S. 1989. Real Exchange Rates, Devaluation and Adjustment. Cambridge: The MIT Press.

Edwards, S. 1999. "How Effective are Capital Controls?" Journal of Economic Perspectives 13 (4): 65-84.

Eichengreen, B., and M. Mussa. 1998. "Capital Account Liberalization: Theoretical and Practical Aspects." Occasional Paper, No. 172, Washington, DC: International Monetary Fund.

Eichengreen, B. and A. Rose. 2014. "Capital Controls in the 21st Century." Journal of International Money and Finance 48: 1-16.

Erten, B. and J.A. Ocampo. 2017. "Macroeconomic Effects of Capital Account Regulations." IMF Economic Review 65 (2): 193-240.

Farhi, E. and I. Werning. 2012. "Dealing With the Trilemma: Optimal Capital Controls With Fixed Exchange Rates." NBER Working Paper No. 18199.

Farhi, E. and I. Werning. 2014. "Dilemma not Trilemma? Capital Controls and Exchange Rates with Volatile Capital Flows." IMF Economic Review 62: 569-605.

Farhi, E. and I. Werning. 2016. "A Theory of Macroprudential Policies in the Presence of Nominal Rigidities." Econometrica 84 (5): 1645-1704.

Fernández, A., Rebucci, A., \& Uribe, M. 2015. "Are capital controls countercyclical?" Journal of Monetary Economics 76, 1-14.

Fernández, A., M.W. Klein, A. Rebucci, M. Schindler, and M. Uribe. 2016. "Capital Control Measures: A New Dataset." IMF Economic Review 64: 548-574.

Fisher, I. 1933. "The Debt-Deflation Theory of Great Depressions." Econometrica 1(4): 337-57.

Fischer, S. 2003. "Globalization and Its Challenges." American Economic Review: Papers and Proceedings 93(2): 1-30.

Forbes, K.J., 2007. "One cost of the Chilean capital controls: Increased financial constraints for smaller traded firms," Journal of International Economics 71(2): $294-323$

Forbes, K.J., M. Fratzscher and R. Straub. 2015. "Capital-flow management measures: What are they good for?" Journal of International Economics, 96: S76-S97.

Forbes, K.J., M. Fratzscher, T. Kostka, and R. Straub. 2016. "Bubble Thy Neighbor: Portfolio Effects and Externalities from Capital Controls." Journal of International Economics 99: 85-104.

Frenkel, J.A. 1983. "Panel Discussion on the Southern Cone." IMF Staff Papers 30 (1): 164-173. 
G-20 (Group of Twenty). 2011. "G-20 Coherent Conclusions for the Management of Capital Flows Drawing on Country Experiences." http://www.g20.org/

G-24 (Group of Twenty-Four). 2011. "Intergovernmental Group of TwentyFour on International Monetary Affairs and Development Communiqué." 11 April. Washington, DC: IMF and World Bank.

Galí, J. 2015. Monetary policy, inflation, and the business cycle: an introduction to the New Keynesian framework and its applications. Princeton and Oxford: Princeton University Press.

Gallagher, K.P., S. Griffith-Jones, and J.A. Ocampo. 2012. Regulating Global Capital Flows for Long-Run Development. Boston: Pardee Center.

Gallagher, K.P. and J.A. Ocampo. 2013. "IMF's New View on Capital Controls." Economic and Political Weekly 48 (12): 10-13.

Gallego, F., L. Hernandez, and K. Schmidt-Hebbel. 2002. "Capital Controls in Chile: Were They Effective?" in Banking, Financial Integration, and International Crises. edited by L. Hernandez and K. Schmidt-Hebbel, 361-412. Santiago, Chile: Central Bank of Chile.

Geanakoplos, J.D., and H.M. Polemarchakis. 1986. "Existence, Regularity, and Constrained Suboptimality of Competitive Allocations When the Asset Market is Incomplete." in Essays in Honor of Kenneth Arrow, Vol. 3. edited by W. Heller, R. Starr, and D. Starrett, 65-95. Cambridge: Cambridge University Press.

Gertler, M., and S. Gilchrist. 1994. "Monetary Policy, Business Cycles, and the Behavior of Small Manufacturing Firms," Quarterly Journal of Economics 109 (2): 309-40.

Ghosh, A.R., J.D. Ostry and M.S. Qureshi. 2017a. "Managing the tide: How do emerging markets respond to capital flows?" IMF Working Paper No. $17 / 69$.

Ghosh, A.R., J.D. Ostry and M.S. Qureshi. 2017b. Taming the Tide of Capital Flows: A Policy Guide Cambridge: MIT Press.

Giordani, P., M. Ruta, H, Weisfeld, and L. Zhu. 2017. "Capital flow deflection." Journal of International Economics 105(C): 102-118.

Gourinchas, P.O., and O. Jeanne. 2006. "The Elusive Gains From International Financial Integration." Review of Economic Studies 73(3): 715-741.

Gourinchas, P.O., and O. Jeanne. 2013. "Capital Flows to Developing Countries: The Allocation Puzzle." Review of Economic Studies 80(4): 14841515.

Greenwald, B.C., and J.E. Stiglitz. 1986. "Externalities in Economies with Imperfect Information and Incomplete Markets." Quarterly Journal of Economics 90 (2): 229-64. 
Griffith-Jones, S., R. Gottschalk, and X. Ciara. 2003. "The OECD Experience with Capital Account Liberalization." in United Nations Conference on Trade and Development, Management of Capital Flows: Comparative Experiences and Implications for Africa, Part 2, New York and Geneva: United Nations, April.

Gupta, P., and O. Masetti. 2018. "Capital flow measures: structural or cyclical policy tools?" Policy Research Working Paper 8418, World Bank.

Hart, O. 1975. "On the Optimality of Equilibrium When the Market Structure is Incomplete." Journal of Economic Theory 11: 418-443.

Henry, P.B., 2007. "Capital account liberalization: Theory, evidence, and speculation." Journal of Economic Literature 45(4): 887-935.

Hutchison, M.M., G.K. Pasricha, and N. Singh. 2012. "Effectiveness of Capital Controls in India: Evidence from the Offshore NDF Market." IMF Economic Review 60 (3): 395-438.

IMF. 2012. "The Liberalization and Management of Capital Flows: An Institutional View." Washington, DC: International Monetary Fund, November 14 th.

Jeanne, O., A. Subramanian, and J. Williamson. 2012. "Who Needs to Open the Capital Account?" Washington, DC: Peterson Institute for International Economics.

Jeanne, O. and A. Korinek. 2010. "Excessive Volatility in Capital Flows: A Pigouvian Taxation Approach." American Economic Review 100 (2): 403407.

Jeanne, O. and A. Korinek. 2013. "Macroprudential Regulation Versus Mopping Up After the Crash." NBER Working Paper No. 18675.

Jeanne, O. and A. Korinek. 2019. "Macroprudential Regulation Versus Mopping Up After the Crash." Review of Economic Studies, forthcoming.

Jinjarak, Y., I. Noy, and H. Zheng. 2013. "Capital controls in Brazil - Stemming a tide with a signal?" Journal of Banking and Finance 37: 2938-2952.

Jordà, Ò., M. Schularick, and A.M. Taylor. 2011. "Financial crises, credit booms, and external imbalances: 140 years of lessons." IMF Economic Review, 59(2): 340-378.

Kaplan, E. and D. Rodrik. 2002. "Did the Malaysian Capital Controls Work?" in Preventing Currency Crises in Emerging Markets. edited by S. Edwards and J.A. Frankel, 393-440. Chicago: University of Chicago Press for the NBER.

Kiyotaki, N., and J. Moore. 1997. "Credit Cycles." Journal of Political Economy 105 (2): 211-48.

Klein, M.W. 2012. "Capital Controls: Gates and Walls." Brookings Papers on Economic Activity 2012 (1): 317-367. 
Korinek, A. 2007. "Dollar Borrowing in Emerging Markets." Dissertation, Columbia University.

Korinek, A. 2010. "Regulating capital flows to emerging markets: An externality view." SSRN Working Paper.

Korinek, A. 2011a. "Excessive Dollar Borrowing in Emerging Markets." Manuscript, University of Maryland. http://dx.doi.org/10.2139/ssrn. 967524

Korinek, A. 2011b. "The new economics of prudential capital controls: A research agenda." IMF Economic Review 59 (3): 523-561.

Korinek, A. 2016. "Currency Wars or Efficient Spillovers?" NBER Working Paper No. 23004.

Korinek, A. 2018. "Regulating capital flows to emerging markets: An externality view." Journal of International Economics 111: 61-80.

Korinek, A. and D. Sandri. 2016. "Capital Controls or Macroprudential Regulation?" Journal of International Economics 99(S1): S27-S42.

Korinek, A. and A. Simsek. 2016. "Liquidity Trap and Excessive Leverage." American Economic Review 106(3): 699-738.

Kose, M.A., E. Prasad, K.S. Rogoff, and S.-J. Wei. 2003. "Effects of Financial Globalization on Developing Countries: Some Empirical Evidence." IMF Occasional Paper 220. Washington: International Monetary Fund.

Kose, M.A. and M.E. Terrones. 2005. "Growth and Volatility in an Era of Globalization." IMF Staff Papers 52: 31-63.

Kose, M.A., E.S. Prasad, K.S. Rogoff, and S.-J. Wei. 2009. "Financial Globalization: A Reappraisal." IMF Staff Papers 56(1): 8-62

Kose, M.A., E.S. Prasad, and A.D. Taylor. 2011. "Thresholds in the process of international financial integration." Journal of International Money and Finance 30: 147-179.

Krugman, P.R. 1979. "A Model of Balance-of-Payments Crises." Journal of Money, Credit and Banking 11(3): 311-325.

Krugman, P.R. 1999a. "Balance Sheets, The Transfer Problem, and Financial Crises." in International Finance and Financial Crises: Essays in Honor of Robert P. Flood Jr., edited by P. Isard, A. Razin and A. Rose. Washington, DC: International Monetary Fund: 31-44.

Krugman, P.R. 1999b. "What happened to Asia?" In Global competition and integration. Ed. by R. Sato, R.V. Ramachandran and K. Mino: 315-327.

Laban, R.M. and F. Larrain. 1998. "The Return of Private Capital to Chile in the 1990s: Causes, Effects, and Policy Reactions." Faculty Research Working Paper Series R98-02, Cambridge, MA: Harvard University, John F. Kennedy School of Government. 
Laban, R.M., F. Larrain, and R. Chumacero. 1997. "What Determines Capital Inflows? An Empirical Analysis for Chile." Faculty Research Working Paper Series R97-09, Cambridge, MA: Harvard University John F. Kennedy School of Government.

Lahiri, A. and C.A. Végh. 2003. "Delaying The Inevitable: Interest Rate Defense And Balance Of Payments Crises." Journal of Political Economy 111(2): 404-424.

Laibson, D. 1997. "Golden eggs and hyperbolic discounting." Quarterly Journal of Economics 112(2): 443-477.

Lambert, F.J., J. Ramos-Tallada, and C. Rebillard. 2011. "Capital Controls and Spillover Effects: Evidence from Latin-American Countries." Banque de France Working Paper No. 357.

Laurens, B. and L. Cardoso. 1998. "Managing Capital Flows: Lessons from the Experience of Chile." IMF Working Paper 98/168.

Le Fort, G. and C. Budnevich. 1998. "Capital Account Regulations and Macroeconomic Policy: Two Latin Experiences." in Capital Account Regimes and the Developing Countries, edited by G.K. Helleiner. United Nations Conference on Trade and Development.

Lorenzoni, G. 2008. "Inefficient Credit Booms." Review of Economic Studies 75(3): 809-833.

Lucas, R. 1990. "Why Doesn't Capital Flow from Rich to Poor Countries." American Economic Review 80 (2): 92-6.

Ma, C. 2019. "Financial stability, growth and macroprudential policy." Journal of International Economics, forthcoming.

Magud, N.E., C.M. Reinhart, and K.S. Rogoff. 2018. "Capital controls: Myth and reality - A portfolio balance approach." Annals of Economics and Finance 19(1): 1-47.

McKinnon, R.I. and H. Pill. 1997. "Credible Economic Liberalizations and Overborrowing." American Economic Review 87(2): 189-193.

McKinnon, R.I. and H. Pill. 1998. "International Overborrowing: A Decomposition of Credit and Currency Risks." World Development 26(7): 1267-1282.

Mendoza, E.G. 2005. "Real Exchange Rate Volatility and the Price of Nontradables in Sudden-Stop-Prone Economies." Economia 6 (1): 103-148.

Mendoza, E.G. 2010. "Sudden Stops, Financial Crises and Leverage." American Economic Review 100(5): 1941-1966.

Obstfeld, M., and K.S. Rogoff. 1996. Foundations of International Macroconomics. Cambridge: MIT Press.

Montecino, J.A., 2018. "Capital controls and the real exchange rate: Do controls promote disequilibria?" Journal of International Economics, 114, 80-95. 
Montiel, P. and C.M. Reinhart. 1999. "Do capital controls and macroeconomic policies influence the volume and composition of capital flows? Evidence from the 1990s." Journal of International Money and Finance, 18(4): 619635 .

Ocampo, J.A. 2008. "A Broad View of Macroeconomic Stability." In The Washington Consensus Reconsidered, chapter 6: 63-94. Edited by N. Serra and J.E. Stiglitz. New York: Oxford University Press.

Ocampo, J.A. 2017. Resetting the International Monetary (Non)System, WIDER Studies in Development Economics, Oxford: Oxford University Press.

Ocampo, J.A., and C. Tovar. 2003. "Colombia's Experience with Reserve Requirements on Capital Inflows." CEPAL Review 81: 7-31.

Ocampo, J.A. and J.G. Palma. 2008. "The role of preventative capital account regulations." The Initiative for Policy Dialogue Series, 170, Columbia University.

OECD. 2019. OECD Code of Liberalisation of Capital Movements. http://www. oecd.org/investment/codes.htm

Ostry, J.D., A.R. Ghosh, K. Habermeier, M. Chamon, M.S. Qureshi, and D.B.S. Reinhardt. 2010. "Capital Inflows: The Role of Controls." IMF Staff Position Note 10/04. Washington: International Monetary Fund.

Ostry, J.D., A.R. Ghosh, K. Habermeier, L. Laeven, M. Chamon, M.S. Qureshi, and A. Kokenyne. 2011a. "Managing Capital Inflows: What Tools to Use?" IMF Staff Discussion Note 11/6. Washington: International Monetary Fund.

Ostry, J.D., A.R. Ghosh, M. Chamon, M.S. Qureshi. 2011b. "Capital Controls: When and Why?" IMF Economic Review 59(3): 562-580.

Ostry, J.D., A.R. Ghosh, M. Chamon, and M.S. Qureshi. 2012. "Tools for managing financial stability risks from capital inflows." Journal of International Economics 88: 407-421.

Quinn, D. 1997. "The Correlates of Change in International Financial Regulation." American Political Science Review 91(3): 531-551.

Quinn, D., S. Martin, and A.M. Toyoda. 2011. "Assessing Measures of Financial Openness and Integration." IMF Economic Review 59(3): 488-522.

Pasricha, G.K., Falagiarda, M., Bijsterbosch, M. and Aizenman, J., 2018. "Domestic and multilateral effects of capital controls in emerging markets." Journal of International Economics, 115, 48-58.

Prasad, E., R.G. Rajan, and A. Subramanian. 2007. "Foreign Capital and Economic Growth." Brookings Papers on Economic Activity 1: 153-209.

Rebucci, A., and C. Ma. 2019. "Capital Controls: A Brief Survey of the New Literature." Manuscript, Johns Hopkins University. 
Reinhart, C.M., and K.S. Rogoff. 2009. This Time is Different: Eight Centuries of Financial Folly Princeton: Princeton University Press.

Reinhart, C.M. and T. Smith, 1998. "Too Much of a Good Thing: The Macroeconomic Effects of Taxing Capital Inflows." In R. Glick, editor. Managing Capital Flows and Exchange Rates: Perspectives from the Pacic Basin. Cambridge: Cambridge University Press, 436-464.

Reinhart, C.M. and T. Smith. 2002. "Temporary Controls on Capital Inflows." Journal of International Economics 57 (2): 327-351.

Rodrik, D. 1998. "Who Needs Capital-Account Convertibility?" In Should the IMF Pursue Capital-Account Convertibility? edited by Stanley Fischer and others. Essays in International Finance no. 207. International Finance Section, Department of Economics, Princeton University.

Rodrik, D. 2008. "The Real Exchange Rate and Economic Growth." Brookings Papers on Economic Activity 39 (2): 365-439.

Rodrik, D. and A. Subramanian. 2009. "Why Did Financial Globalization Disappoint?" IMF Staff Papers 56 (1): 112-138.

Rossi, M. 1999. "Financial Fragility and Economic Performance in Developing Economies; Do Capital Controls, Prudential Regulation and Supervision Matter?" IMF Working Papers 99/66.

Saborowski, C., S. Sanya, H. Weisfeld, and J. Yepez. 2014. "Effectiveness of Capital Outflow Restrictions." IMF Working Paper. WP/14/8.

Schindler, M. 2009. "Measuring financial integration: A new data set." IMF Staff Papers 56: 222-238.

Schmitt-Grohé, S. and M. Uribe. 2016. "Downward Nominal Wage Rigidity, Currency Pegs, and Involuntary Unemployment." Journal of Political Economy 124(5): 1466-1514.

Stiglitz, J.E. 1982. "The Inefficiency of the Stock Market Equilibrium." Review of Economic Studies 49(2): 241-61.

Stiglitz, J.E. 2002. Globalization and Its Discontents. New York: W. W. Norton.

Summers, L. 2000. "International Financial Crises: Causes, Prevention, and Cures." American Economic Review 90(2): 1-16.

Sunstein C.R. and R.H. Thaler. 2003. "Libertarian Paternalism Is Not an Oxymoron." University of Chicago Law Review 70(4): 1159-1202.

Tamirisia, N. 2004. "Do Macroeconomic Effects of Capital Controls Vary by Their Type? Evidence from Malaysia." IMF Working Paper 04/3.

Valdes-Prieto, S. and M. Soto. 1995. "New Selective Capital Controls in Chile: Are They Effective?" Universidad Catolica de Chile, Mimeo.

Weitzman, M. 1974. "Prices vs. Quantities." Review of Economic Studies 41(4): 477-491. 
Woodford, M. 2004. Interest and prices: Foundations of a theory of monetary policy. Princeton: Princeton University Press.

Villar, L. and H. Rincón. 2003. "The Colombian economy in the nineties: capital flows and foreign exchange regimes." in Critical Issues in Financial Reform: A View from the South, composed by A. Berry (comp.), New Brunswick, New Jersey: Transaction Publishers. 